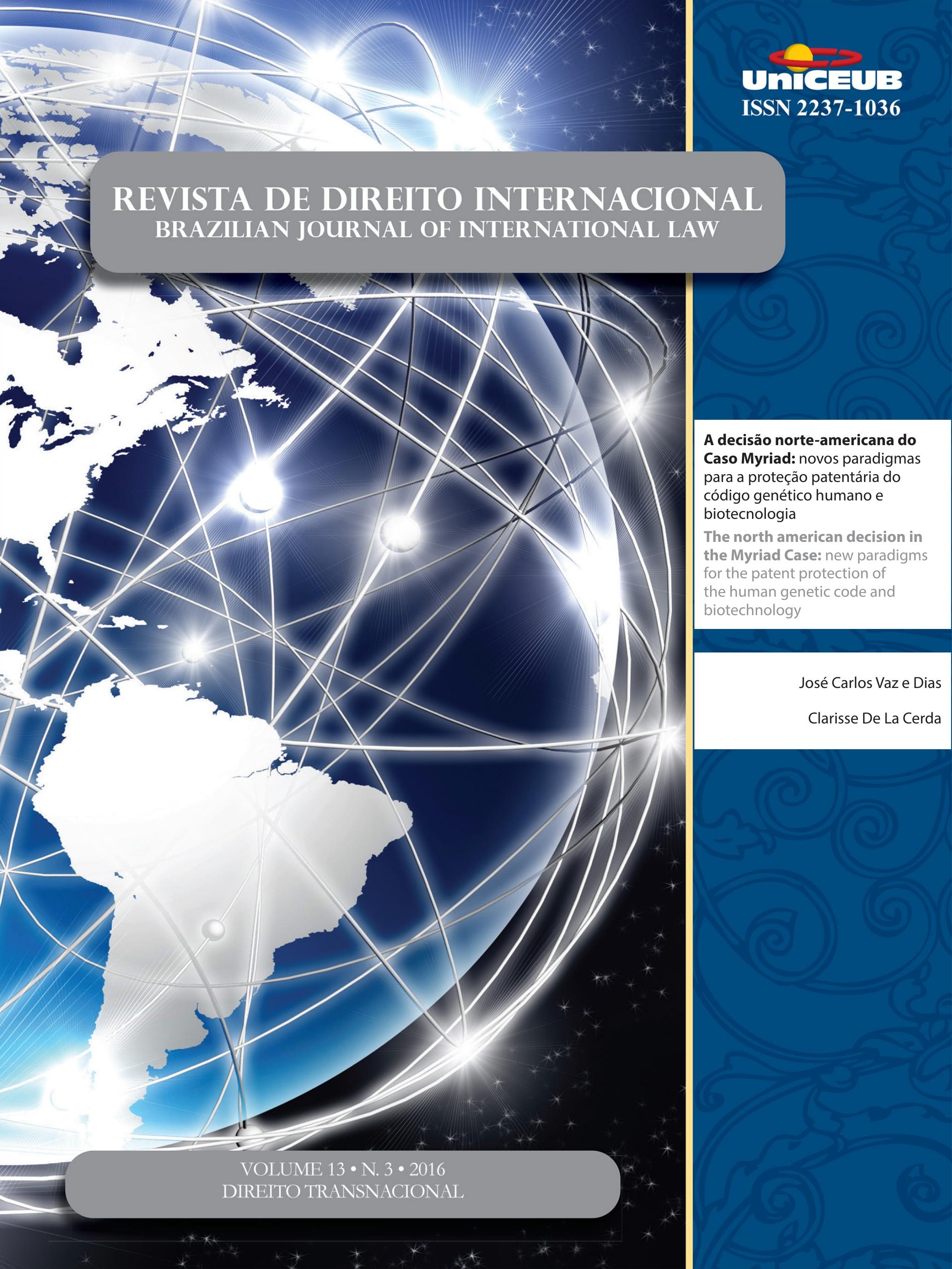


Crônicas da ATUALIdAde do direito internacional .................................................. 2

I. Dossiê Temático: Direito Transnacional .........................................................15

EDITORIAL: O Direito Transnacional - Circulação de normas e relações jurídicas transnacionais .......16 Priscila Pereira de Andrade

A emergênCia do direito transnacional ambiental .............................................18 Priscila Pereira de Andrade

Desafíos y RESPUESTAS TRANSNACIONALES FRENTE A LOS CRÍMENES AMBIENTALES ...............30 Rosmerlin Estupiñan-Silva

DiREITO TRANSNACIONAL E MUdANÇAS CLIMÁTICAS .50 Géraud de Lassus Saint-Geniès

Especies en movimiento: la Convención sobre el Comercio Internacional de Especies Amenazadas de Fauna y Flora Silvestres como espacio de “Encuentro” de discursos, ACTORES Y ESTRATEGIAS EN EL DERECHO AMBIENTAL TRASNACIONAL

María Valeria Berros e Dabel Leandro Franco

El carácter transnacional del Sistema comunitario de ECogestion « Eco-ManageMENT AND Audit SCHEME » (EMAS) DENTRo de LA UE y MÁs ALlÁ DE SUS Fronteras ......72 Adélie Pomade

O CONCEITO DE CONDUTA EMPRESARIAL RESPONSÁVEL À LUZ DOS ORDENAMENTOS JURÍDICOS BRASILEIRO, INTERNACIONAL E TRANSNACIONAL

Gabriel Webber Ziero

ARBITRAGEM NO DIREITO TRIBUTÁRIO INTERNACIONAL E NO DIREITO INTERNACIONAL DOS INVESTIMENTOS: UMA MANIFESTAÇÃO DO DIREITO TRANSNACIONAL

Vivian Daniele Rocha Gabriel 
O DIREITO TRIBUTÁRIO SOB UMA PERSPECTIVA TRANSNACIONAL

Franciele de Simas Estrela Borges

As Características do Direito Transnacional como Metodologia: Análise sob o enfoQue dos Aspectos Processuais da Arbitragem 126

Flávia Foz Mange

O DIREITO TRANSNACIONAL (“GLOBAL LAW") E A CRISE DE PARADIGMA DO ESTADO-CENTRISMO: É POSSÍVEL CONCEBER UMA ORDEM JURÍDICA TRANSNACIONAL? ...................................... 146

Luiza Nogueira Barbosa e Valesca Raizer Borges Moschen

TransPorte AÉREO E DIREITO TRANSNACIONAL: DA CONVERGÊNCIA À UNIFORMIDADE 160 Mickael R. Viglino

Outros Artigos. 175

O Fundo Monetário Internacional e a proteção dos direitos humanos: uma análise DO PROGRAMA DE CRESCIMENTO E REDUÇÃO DA POBREZA NO HAITI 177

Pablo Henrique Hubner de Lanna Costa e Carlos Alberto Simões de Tomaz

Um estranho no ninho? Padrões privados no Acordo de Barreiras Técnicas ao CoMÉRCIO DA OMC 192

Michelle Ratton Sanchez Badin e Marina Yoshimi Takitani

Os benefícios tributários do programa Inovar-Auto e os princípios da Nação Mais Favorecida e do Tratamento Nacional: uma análise dos argumentos dos Painéis atualmente em Curso contra o Brasil no Órgão de SoluÇão de Controvérsias da OMC . 211 Eric Moraes Castro e Silva

A ERA DA HUMANIDADE: REFLEXões PARA A HISTÓRIA DO DIREITO INTERNACIONAL 236 Henrique Weil Afonso

Precedentes vinculantes nos Estados Unidos da América e no direito brasileiro: Um ESTUDO COMPARADO 264

Patrícia Perrone Campos Mello 
IL DIRITTO AMBIENTALE SECONDO L'OTTICA DEL DIRITTO COSTITUZIONALE POSITIVO E LA RESPONSABILITÀ PER DANNI ALL'AMBIENTE NEL DIRITTO COMUNITARIO: LO STATO DELL'ARTE DEL DIRITTO AMBIENTALE COSTITUZIONALE E COMUNITARIO 287

Elcio Nacur Rezende

DA DESCONSIDERAÇÃo DA PERSONALIDADE JURÍDICA NAS RELAÇÕES CONSUMEIRISTAS BRASILEIRAS: ANÁLISE À LUZ DAS TEORIAS CLÁSSICAS

Daniel Amin Ferraz e Marcus Vinicius Silveira de Sá

ANALYSIS OF ADVANTAGES AND DISADVANTAGES OF FORUMS PRESCRIBED UNDER THE UNCLOS AND STATE PRACTICE: THE WAY AHEAD FOR INDIA ......................................................319

Vinai Kumar Singh

Do governo POR LEIS À governanÇA POR NúMERos: breve anÁlise do Trade in SERVICE AgreEMENT (TISA) ...............................................................................338 Jânia Maria Lopes Saldanha, Rafaela da Cruz Mello e Têmis Limberger

As DIRETIVAS EUROPEIAS COMO NORMA REGULADORA DO DIREITO ADMINISTRATIVO GLOBAL ..356 Alice Rocha da Silva e Ruth Maria Pereira dos Santos

O desenVolvimento da POlítica AGRícola COMUM dA UNião EUROPEIA 375 Tatiana de A. F. R. Cardoso Squeff

A imunidade de Jurisdição das organizaÇões internacionais FaCE AO Direito de aCESSO À JUSTIÇA 391

Fernanda Araújo Kallás e Caetano

O DIREITO INTERNACIONAL ENTRE O DEVER ÉTICO E A AÇÃo POLÍ́TICA: OS FUNDAMENTOS DE UM DEVER DE COOPERAÇÃO INTERNACIONAL NA FILOSOFIA POLÍTICA DE IMMANUEL KANT .405 Ademar Junior Pozzatti

EXTENSÃo E FRAGMENTAÇÃo NO CONTEXTO DA JURISDIÇÃO PENAL INTERNACIONAL .423 Marcus Vinícius Xavier de Oliveira

A DEFINiÇÃo JURÍdiCA DA "COMUNIDADE" .444 Nitish Monebhurrun, Michelle Lucas Cardoso Balbino, Fernanda Castelo Branco Araujo, Othon Pantoja, Míara Bogo Bruno e Cândida Dettenborn Nóbrega 
Comparative Study on Chinese Local Legislation of Science and Technology ProGRESS

LI Xiaoming e LI Yihan

O CONTROLE PENAL DO TRÁFICO DE PESSOAS: CONSTRUÇÃO JURÍDICA, INTERAÇÕES ORGANIZACIONAIS E COOPERAÇÃO INTERNACIONAL

Bruno Amaral Machado e Priscilla Brito Silva Vieira

Desativismo judicial: a extradição Battisti no Supremo Tribunal Federal .505 Francisco Rezek e Israel Paulino

A decisão norte-americana do Caso Myriad: novos paradigmas para a Proteção patenTÁRIA DO CÓDIGO GENÉTICO HUMANO E BIOTECNOLOGIA 514 José Carlos Vaz e Dias e Clarisse De La Cerda 


\section{A decisão norte-americana do Caso Myriad: novos paradigmas para a proteção patentária do código genético humano e biotecnologia*}

\author{
The north american decision in the Myriad \\ Case: new paradigms for the patent protection \\ of the human genetic code and biotechnology
}

José Carlos Vaz e Dias**

Clarisse De La Cerda***
* Recebido em 15/09/2016

Aprovado em 30/01/2017

** José Carlos Vaz e Dias é Doutor em Direito da Propriedade Intelectual e Investimento Estrangeiro pela Universidade de Kent -Inglaterra. Professor Adjunto em Direito da Propriedade Intelectual pela Universidade do Estado do Rio de Janeiro (UERJ) e sócio do escritório Vaz e Dias Advogados \& Associados. E-mail: jose.dias@vdav.com.br

** Mestre em Direito pela UERJ e advogada na área de contratos de transferência de tecnologia.E-mail: cladelacerda@gmail.com

\section{Resumo}

Este artigo aborda as questões proprietárias das invenções biotecnológicas e os parâmetros determinados pelo Caso Myriad, emitido pela Suprema Corte Norte-Americana em 2013. As patentes sobre sequências genéticas e organismos vivos são temas de controvérsias no cenário da propriedade intelectual, pelo impacto nas atividades empresariais e geração de negócios e perspectiva de lucratividade. Por envolver a propriedade de matérias da natureza, existem questões morais e éticas também sobre o tema, principalmente alegações relativas ao homem brincando de Deus e o desrespeito à lei divina em não criar novas espécies de seres vivos. $\mathrm{O}$ foco central do artigo é discutir se os variados materiais genéticos isolados por intervenção humana seriam verdadeiras invenções ou meras descobertas, sendo que as descobertas estão fora do escopo d proteção patentária, conforme determinado pelas principais convenções internacionais na área do direito da propriedade intelectual. Para tanto, o Caso Myriad é abordado, assim como a proteção patentária no Brasil para a biotecnologia. Essa decisão judicial aprofundou aspectos técnicos ligados à patenteabilidade de seres vivos e identificou parâmetros e limites para proteção patentária. A referida decisão da Suprema Corte alterou o cenário de proteção, bem como influenciou os parâmetros de investimento na área biotecnológica. Ela pode servir também para a construção de um novo regramento para promoção patentária das invenções biotecnológicas, seguindo a necessidade de atendimento ao fim constitucional do desenvolvimento tecnológico.

Palavras chaves: propriedade intelectual, patentes, invenções biotecnológicas,

\section{Abstract}

This article addresses the proprietary matters linked to biotechnology inventions and the main protection parameters set out by the Myriad Case, issued by the American Supreme Court in 2013. The patents on genetic sequences and life organisms are themes of controversies on intellectual property due to the technology impact in the commercial activities and ge- 
neration of business and profit perspectives. Since patents are related to living matters, there are also moral and ethical questions on property matters, mainly allegations of man playing as God and the accusation of disrespecting divine laws based on the compromise not to create new species of living organisms. The focus of this article is to discuss if the various genetic materials isolated by human intervention would be inventions or mere discoveries, taking into account that discoveries are outside the scope of patent protection, as provided by the main international conventions in the intellectual property law. Therefore, the Myriad Case will be addressed as well as the patent protection in Brazil for biotechnology. This court decision deepened the examination of technical aspects related to the patentability of living matters and established the limits of protection. The aforementioned decision issued by the Supreme Court altered the scenario for the protection of this type of technology as well as influenced the investments in the biotechnology area. The decision may also service to as instrument to tailor a new ruling for biotech patent protection of in Brazil, following the local needs and the constitutional purpose of technological development.

Keywords: intellectual property, patents, biotechnological inventions.

\section{INTRODUÇÃo}

Uma mudança significativa ocorreu em 13 de junho de 2013 quanto à proteção e apropriação proprietária de seres vivos, especificamente do código genético humano. A Suprema Corte Norte-Americana (Suprema Corte) julgou, naquela data, o Caso Myriad ${ }^{1}$, que envolveu a validade e a eficácia do patenteamento outorgado pelo United States Patent Office (USPTO) às sequencias genéticas da Myriad Genetics Inc. (Myriad).

A relevância da decisão refere-se à mudança da tendência sedimentada nos Estados Unidos e na União Europeia e Japão sobre a proteção patentária aos desenvolvimentos tecnológicos ligados à vida, principalmente as sequências genéticas isoladas. Cumpre salientar que o entendimento até então prevalecente na doutrina e

1 Association for Molecular Pathology v. Myriad Genetics Inc. Supreme Court of the United States. Processo no. 569 U.S. 12-398 (2013). julgados foi no sentido de aceitar o patenteamento de produtos da natureza, desde que isolados e/ou manipulados pelo homem e atendidos os requisitos de patenteabilidade.

Deve-se ressaltar, neste sentido, a decisão da Suprema Corte no Caso Chakrabarty ${ }^{2}$, que expressou a máxima "everthing under the Sun that is made by man [may be patentable]" e, consequentemente, incluiu por completo os organismos vivos no rol das invenções patenteáveis, desde que sofressem alguma intervenção intelectual humana.

Indagam-se quais foram os fundamentos e justificativas que levaram os juízes da Suprema Corte Americana a adotarem posicionamento distinto do sedimentado pelo USPTO no Caso Myriad. Este questionamento justifica-se pelo fato de a biotecnologia ser reconhecidamente um instrumento para diversas soluções que atingem a saúde humana, animal e o aumento da produção agrícola. As perspectivas mercadológicas e de negócios são inúmeras ${ }^{3}$.

Deve-se relembrar os argumentos de natureza ética contrários à patenteabilidade de seres vivos, principalmente ao código genético, baseados ao fato de organismos da natureza serem criações de Deus, não podendo assim ser objeto de propriedade ${ }^{4}$. Esses argumentos persistem e são frequentemente trazidos à tona como contraposição à liberdade de criação na área biotecnológica.

2 DIAMOND v. CHAKRABARTY, (1980). 447 U.S. 303 (1980). Disponivel em https://supreme.justia.com/cases/federal/ us/447/303/case.html. Acesso em 3 de setembro de 2016

3 Veja a reportagem "Blanver adquire $100 \%$ de participação da CYG Biotech" publicada em 11/03/2016 que aborda o mercado de pesquisa, desenvolvimento e produção de medicamentos na área da biotecnologia. Disponível em http://www.investimentosenoticias. com.br/noticias/saude/blanver-adquire-100-de-participacao-dacyg-biotech. Acesso em 2 de setembro de 2016. Veja também artigo publicado por NAVES, Bruno Torquato de Liveira e GOIATÁ, Sarah Rego. "Patentes de Genes Humanos". Disponível em http:// www.publicadireito.com.br/artigos/?cod=6d9bffd3b6ec2641. Acesso em 1 de setembro de 2016.

4 Veja a reportagem "Patented Genes: an Ethical appraisal", em que um grupo de 200 religiosos norte-americanos formaram uma só voz em 1995, em torno do patenteamento de partes ou todo de animais e humanos, como segue: "We, the undersigned religious leaders, oppose the patenting of human and animal life forms. We are disturbed by the U.S. Patent Office's recent decision to patent body parts and several genetically engineered animals. We believe that humans and animals are creations of God, not humans, and as such should not be patented as human inventions."Disponível em http://issues.org/14-3/sagoff/. Acesso em 29 de agosto de 2016. 
A fase mais contundente dos questionamentos ao patenteamento de seres vivos e, também, de invenções biotecnológicas em geral, ocorreu entre o período de 1950 a 1990. Nos anos 80, o USPTO emitiu diretrizes no sentido de implementar a decisão do Caso Chakrabarty e, assim, aceitar a sequência de DNA isolada e purificada como invenção tecnológica patenteável, bem como partes de seres vivos, incluindo plantas ${ }^{5}$ e animais. As discussões sobre moralidade, crenças religiosas e bons costumes foram inevitáveis, seja nos Estados Unidos, países europeus e no Brasil.

A Comissão da Comunidade Europeia publicou a "Proposta para uma Diretiva do Conselho para a Proteção Legal de Invenções Biotecnológicas" em 1988 e discussões acaloradas também ocorreram sobre os limites da proteção patentária às criações da vida com a prevalência da possibilidade de patenteamento de seres vivos, excluindo as variedades de plantas e animais.

No Brasil, a lei da propriedade intelectual (Lei no. 9.279, de 14 de maio de 1996) ${ }^{7}$ vedou terminantemente o patenteamento de partes e todo de seres vivos no Brasil, sendo que o radicalismo impede a pesquisa e o desenvolvimento da pesquisa local, principalmente na área de fármacos, e prevalece aspectos religiosos e políticos de inserção do Brasil dentro do comércio internacional de intangíveis.

Tendo em vista a perspectiva acima referenciada, o presente artigo objetiva detalhar e discutir os principais aspectos que envolveram o Caso Myriad e a base da decisão do referido caso na Suprema Corte, pontuando seus argumentos.

Assim, será abordado o desenvolvimento legal ligado à proteção das invenções biotecnológicas, para ser possível identificar as indagações existentes que freiam e os argumentos que promovem a extensão do sistema de patentes para as criações da vida, bem como as decisões paradigmáticas para essa proteção, a partir da análise do Caso Myriad.

\footnotetext{
5 United States Plant Patent Act 35 U.S.Ch.15.

6 Proposal for a Council Directive on the Legal Protection of Biotechnological Inventions. COM (88) 496. Final. 17/10/1988. Disponível em http://aei.pitt.edu/3814/. Acesso em 29 de agosto de 2016. As discussões sobre a Proposta do Conselho encerraram em -06/07/1998, quando a Diretiva 98/44/CE foi promulgada pelo Parlamento Europeu. Disponível em: http://www.cgcom.es/europa_al_dia/2001/54. Acesso em 29 de agosto de 2016.

7 Lei n. 9.279, de 14 de maio de 1996. Disponível em http:// www.planalto.gov.br/ccivil_03/leis/L9279.htm. Acesso em 5 de setembro de 2016.
}

Nesta mesma dinâmica, será abordada a proteção patentária às invenções biotecnológicas no Brasil, especialmente quanto às sequências genéticas, que, em razão da sua dificuldade de interpretação legislativa e prática, tem levado pesquisadores brasileiros a buscarem proteção em outros países com legislações mais liberais ${ }^{8}$

Como capítulo central está a abordagem, em detalhes, das bases do Caso Myriad e o resultado efetivo da decisão pelos membros da Suprema Corte. Neste ponto, será explicitado como essa decisão interfere na proteção patentária de seres vivos e quais foram os principais argumentos relevados pela Suprema Corte para reverter a proteção crescente aos seres vivos.

\section{Apropriação Proprietária de Produtos da Biotecnologia: Desenvolvimentos e Restrições Legais}

\subsection{A necessidade de proteção às criações intelectuais}

A palavra biotecnologia é compreendida sob diferentes perspectivas e em diferentes contextos. Ela pode relacionar-se ao estudo da biologia e desenvolvimento de novas tecnologias para a saúde humana e animal, à exploração eficaz do meio ambiente e às questões jurídicas e éticas relacionadas à exploração e apropriação de produtos da natureza. Em cada área de influência, a biotecnologia é compreendida de maneira peculiar sendo denominador comum o fato de ser um instrumento eficaz para a promoção do bem-estar do homem.

De acordo com o Artigo 2 (Utilização dos Termos para os Propósitos desta Convenção) da Convenção sobre Diversidade da ONU, a biotecnologia é compreendida como" "qualquer aplicação tecnológica que utilize

8 VIEIRA, Adriana Carvalho Pinto e BUAINAIN, Antonio Marcio et al. "Patenteamento da Biotecnologia no Setor Agrícola no Brasil: Uma Análise Crítica." Revista Brasileira de Inovação (Rio de Janeiro) (9) 2. Pags. 323 a 354. Disponível em http://docplayer. com.br/13523140-Patenteamento-da-biotecnologia-no-setor-agricola-no-brasil-uma-analise-critica.html. Acesso em 5 de setembro de 2016.

9 A Convenção sobre a Diversidade Biológica é um tratado promovido pela Organização das Nações Unidas que estabelece parâmetros e compromissos para a exploração da diversidade biológica existente na terra. $\mathrm{O}$ texto dessa Convenção foi aprovado na Conferência das Nações Unidas sobre o Meio Ambiente e De- 
sistemas biológicos, organismos vivos, ou seus derivados, para fabricar ou modificar produtos ou processos para utilização específica".

Para o "Dicionário de Biologia Collins", ${ }^{10}$ a biotecnologia é definida como "o uso de organismos, as suas partes e processos, para a fabricação ou produção de substâncias úteis e comerciais. O termo denota um espectro amplo de processos, desde o uso de minhocas como uma fonte de proteína à manipulação genética de bactérias para a produção de insulina e hormônios para crescimento".

A biotecnologia pode envolver a produção de novas substâncias a partir da exploração de organismos vivos ou partes destes. Por meio do uso de técnicas e conhecimentos decorrentes da bioquímica, engenharia genética, microbiologia, química, física, matemática e até mesmo da ciência da computação, a biotecnologia é um instrumento para a inovação, desenvolvimento humano e inserção de novos processos industriais ${ }^{11}$.

No mercado internacional, inúmeras indústrias biotecnológicas estão sendo criadas e fusões entre multinacionais nesta área são notícias corriqueiras, fatos que evidenciam o interesse no crescimento dessa atividade empresária ${ }^{12}$. A produção de fármacos está sofrendo,

senvolvimento, realizada na cidade do Rio de Janeiro, no período entre 5 a 14 de junho de 1992. Ela integra o ordenamento jurídico brasileiro, por meio do Decreto Legislativo no. 2 de 3 de fevereiro de 1994. Disponível em http://legis.senado.gov.br/legislacao/ListaPublicacoes.action?id=139068. Acesso em 30 de agosto de 2016.

10 Dictionary of biology, W.H. Hale and J.P. Margham. Collins reference. Collins. London. 1988.

11 A biotecnologia pode reduzir assim os custos na produção industrial, tal como acontece na indústria farmacêutica em que o uso de microrganismos para a obtenção de fármacos reduz o uso de químicos e os efeitos prejudiciais ao homem. Insere novos produtos e espécies por meio da manipulação de técnicas de DNA recombinante. Para o setor de sementes, novas variedades de plantas traz produtividade ao campo e permite o crescimento de plantas com pequenas quantidades de fertilizantes.

12 A Monsanto e a Bayer AG estão discutindo parcerias na área biotecnológica, que podem envolver a compra dos ativos da Monsanto por essa empresa para a manutenção da competitividade do setor agrícola. As ofertas de aquisição da gigante norte-americana estão no montante de US\$62 bilhões, o que permitirá que a Bayer tenha acesso ao um inúmero incontável de sementes, variedades de plantas e posição estratégica privilegiada no mercado. Disponível em http://br.wsj.com/articles/SB104116731725693645958045821 59580361188536 e com acesso em 10/07/2016. Recentemente, a sociedade chinesa ChemChina adquiriu a líder mundial de produção de cultivos - Syngenta - pelo valor de US\$ 43 bilhões. Disponível em http://cc.bingj.com/cache.aspx?q=compra + da + singenta + por + empresa + chinesa\&d $=4991247455027887 \&$ mkt $=$ pt $-B R \&$ setla

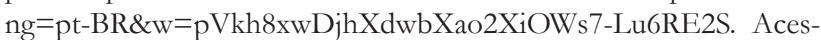

também, fortes modificações por meio da manipulação de incontáveis materiais vivos e processos biotecnológicos, com redução significativa no uso de materiais sintéticos.

Diante da importância ao bem-estar dos seres humanos e impacto na competitividade dos empresários, bem como promoção do comércio internacional, parece ser imperioso garantir que os desenvolvimentos biotecnológicos sejam protegidos pelo direito da propriedade intelectual.

Releva-se que o bem jurídico a ser tutelado é o produto decorrente do exercício da criação humana atrelado à manipulação de seres vivos. Justifica-se a tutela pelo empenho em alcançar um equilíbrio entre o aporte e recuperação de investimentos e o desenvolvimento tecnológico.

O objetivo do direito da propriedade industrial é, em essência, estabelecer meios para que seja vantajoso ao inventor revelar a solução encontrada, impedindo a cópia desautorizada e possibilitando a exploração exclusiva por um período limitado. Com a promoção de invenções, acredita-se no fomento ao desenvolvimento tecnológico, garantindo-se o progresso econômico, científico e tecnológico.

Sob uma perspectiva econômica baseada na história das economias ocidentais, os autores Douglass North e Robert Thomas ${ }^{13}$ explicitam que a propriedade privada é uma criação humana que objetiva determinar os limites dos direitos do proprietário sobre uma coisa ou bem jurídico. Tais limites são relevantes no processo decisório de eficiência crescente dos investimentos e identificação de custos de produção, disponibilizam transparência nos negócios jurídicos, bem como determinam a possibilidade de lucratividade pela exploração comercial.

Um ponto de vista positivo do patenteamento é exatamente este: a revelação do que poderia ser mantido em segredo, a possibilidade de continuidade de desenvolvimento com base naquilo que foi revelado e a perspectiva de garantia de lucratividade dentro dos limites proprietários determinados pela lei.

Assim, a compreensão prevalecente é no sentido de

so em 20 de agosto de 2016.

13 NORTH, Douglas C. \& Robert Paul Thomas. The Rise of the Western World. A New Economic History. Cambridge University Press. 1989. Páginas 1-70.

REALE, Miguel. Lições preliminares de direito civil. 5. ed. São Paulo: Saraiva, 1978. 
incentivar a promoção tecnológica, para que os desenvolvimentos biotecnológicos sejam desenvolvidos e não mantidos em segredo e, assim, possivelmente fora do processo de fabricação ${ }^{14}$.

\subsection{Questionamentos Sobre Patentabilidade de Seres Vivos}

Não obstante o reconhecido impacto positivo da propriedade intelectual sobre a promoção tecnológica, há argumentos contrários ao patenteamento de organismos vivos e/ou suas partes que evidenciam a necessidade de realizar ajustes no sistema de patentes para que a criação intelectual seja enquadrada como invenção tecnológica, bem como enfrentar questões relacionadas à moralidade da propriedade sobre seres vivos ${ }^{15}$.

Passamos a tecer algumas discussões e pensamentos doutrinários e filosóficos que delinearam a proteção para as invenções biotecnológicas e que constituíram bases para as principais decisões judiciais na área. Mesmo entendendo que essas discussões foram relevantes durante o período entre 1950-1990, período em que o escopo de proteção aos produtos da biotecnologia foi fortalecido, elas constantemente retornam face à característica peculiar dessas invenções, quais sejam, serem postas ou derivarem do uso de materiais vivos.

A maior objeção à proteção patentária para os desenvolvimentos biotecnológicos, principalmente plantas e materiais genéticos humanos, decorreu da compreensão limitada do conceito de "aplicação industrial" ou "utili-

14 SCHOLZE, Simone Henriqueta Cossetin. Os direitos de propriedade intelectual e a biotecnologia. Faculdade de Direito da Universidade de Brasília, Agosto de 1997. Disponível em: http://seer. sct.embrapa.br/index.php/cct/article/view/8916/5036 Acesso em 30 de agosto de 2016. p. 49.

15 Torna-se importante ressaltar que a compilação dos questionamentos sobre a patentabilidade de produtos biotecnológicos, incluindo materiais vivos, microrganismos e código genético isolado e manipulado, decorreu de estudos doutrinários realizados durante o período de 1950 a 1994. Acredita-se que a omissão da Convenção da União de Paris sobre proteção de seres vivos abriu uma lacuna para cada país verificar a conveniência dessa proteção.ís. Vide OVERWALLE, Geertrui Van. Patent protection for Plans: A Comparison of American and European Approaches. IDEA. Vol. 39. N. 2. Págs.143-194.Veja também FUNDER, Joshua V. "Rethinking Patents for Plant Inovation”. 1999. EIPR. Issue 11. Págs. 51-577. RAI, Arti K. "Intellectual Property Rights in Biotechnology: Addressing New Technology". Wake Forest Law Review. Vol. 34. Págs. 827-847. BELCHER, Brian e HAW'TIN, Geoffrey. A Patent on Lie. Ownership of Plants and Animal Research. IDRC. Ottawa. 1991. Págs.2-28. dade industrial" ${ }^{16}$. Parte da doutrina ${ }^{17}$ considerava que o sistema de patentes era voltado essencialmente para os desenvolvimentos relacionados à transformação da matéria-prima em produtos manufaturados e à utilização de maquinários e processos de engenharia, incluindo a química nas atividades da indústria ${ }^{18}$. Assim, somente as invenções incidentes ou influenciadoras do processo produtivo industrial poderiam ser passíveis de proteção patentária.

Aliás, esse debate foi muito intenso em alguns países europeus como a Bélgica ${ }^{19}$. Agricultores relevavam que os produtos da natureza manipulados pelo homem não podiam sofrer restrições do sistema de patentes, visto que alguns produtos agrícolas eram adequadamente definidos e manufaturados pela própria indústria, como era o caso dos fertilizantes, maquinários agrícolas e técnicas peculiares de cultivo.

Neste mesmo país, existem relatos de que o conceito de "indústria", no Artigo $1^{\circ}$ do Ato de Patente, era obscuro e trazia imprecisões quanto ao seu enquadramento como manufatura para indústria e, consequentemente, vedações quanto à incorporação dos produtos da natureza. Já na Holanda, a interpretação foi no sentido de recusar a proteção aos seres vivos visto que o conceito de "indústria", do Art. $3^{\circ}$ do Ato de Patente Holandês de 1910, não comportava expressamente os produtos da biotecnologia e/ou seres vivos ${ }^{20}$.

O embate sobre esse posicionamento é evidente, pois, em interpretação contrária, o sistema de patentes era considerado instrumento de proteção das criações ou exercício intelectual humano. Ele englobaria qualquer espécie de invenções desde que sejam utilizáveis ou apli-

16 O requisito da "utilidade industrial" é inerente ao regime norte-americano de patente e tem como aspecto importante a verificação se uma invenção tem um propósito útil para a sociedade, quando analisada de maneira objetiva. Veja 5 U.S.C. \} 1 0 1 \text { (1994). }

17 OVERWALLE, Geertrui Van. Patent Protection for Plants: A comparison of American and European Approaches. IDEA. Vol. 38. N. 2. Pág. 153-155.

18 Do Estatuto dos Monopólios ao Ato Inglês de Patente de 1949, a expressão invenção foi compreendida como material decorrente da engenhosidade humana atrelada à fabricação de produtos, como maquinários ou novos produtos elaborados para uso humano. Veja PHILLIPS, Jeremy e FIRTH, Alison. Introduction to Intellectual property Law. $2^{\text {nd }}$. Ed. Butterworths. Londres. 1990. Pág. 34.

19 OVERWALLE, Geertrui Van. Patent Protection for Plants: A comparison of American and European Approaches. IDEA. Vol. 38. N. 2. Pág. 153.

20 OVERWALLE, Geertrui Van. Patent Protection for Plants: A comparison of American and European Approaches. IDEA. Vol. 38. N. 2. Pág. 1534 
cáveis à indústria, sendo necessário considerar a amplitude do conceito de indústria à evolução da atividade empresarial, como a indústria do agronegócio. Deve-se incluir assim os processos e instrumentos de fabricação, os medicamentos e os produtos e processos decorrentes de seres vivos e os produtos agrícolas, que também poderiam ser processados para fins de consumo humano.

Neste mesmo sentido, o renomado Gama Cerqueira entendia que a expressão "utilização industrial" era um conceito amplo que comportava as invenções utilizáveis na indústria. Mesmo sem uma abordagem específica aos produtos biotecnológicos, este autor explicitou a exclusão do campo de aplicação patentário às criações de natureza puramente científicas, literárias e artísticas, além daquelas não utilizáveis para a produção industrial ${ }^{21}$.

A discussão sobre o escopo de abrangência da "aplicação industrial" passou também pelo questionamento da patenteabilidade dos produtos da natureza e de seres vivos, face ao fato de que produtos da natureza manipulados não são produtos decorrentes de processo criativo humano e não podem ser classificados como invenções ${ }^{22}$.

$\mathrm{O}$ fato de os produtos da biotecnologia estarem em um processo contínuo de mutação dificulta a definição precisa do objeto de uma invenção e restringe a repetição da invenção decorrente do material vivo. Lembre-se que o entendimento prevalecente era no sentido de o sistema de patentes assegurar proteção aos produtos obtidos de processo de transformação radical de matérias-primas, ou seja, da natureza.

Nesse sentido, fortes objeções ocorreram na Europa e nos Estados Unidos quanto ao patenteamento de plantas/animais e suas partes e microrganismos durante o século XX e no período que precedeu a decisão do Caso Chakrabarty ${ }^{23}$.

21 CERQUEIRA, Gama. Tratado da Propriedade Industrial. $2^{\mathrm{a}}$. ed. Ed. RT. Vol. I. 1982. Págs. 339-341.

22 OVERWALLE, Geertrui Van. Patent Protection for Plants: A comparison of American and European Approaches. IDEA. Vol. 38. N. 2. Págs. 148-150. Entende-se que a outorga patentária para um produto da natureza seria assegurar a um único indivíduo o direito de explorar um bem que decorre da criação natural.

23 Os questionamentos passaram pelo entendimento que a concessão de patente para seres vivos, principalmente plantas e suas partes, seria de não uso pois serviria essencialmente para garantir poderes encontrados na natureza e sem utilidade para a promoção do progresso. A vedação ao patenteamento de seres vivos permaneceu dormente nos Estados Unidos ate 1973 quando a decisão do USPTO Board of Appeals, que invalidou patente relativa a serves
Outra dificuldade apontada para justificar o não patenteamento de produtos biotecnológicos foi a impossibilidade de descrição suficiente para as invenções nesta área, principalmente ao patenteamento de plantas e seres vivos ${ }^{24}$.

Para solucionar esse obstáculo, vários países, já na década de 80 , modificaram as suas regras para comportar o patenteamento de seres vivos e exigir o depósito de material biológico em centros depositários específicos na data de requerimento do pedido de patente como uma maneira de suprir o requisito da divulgação. A amostra depositada era disponibilizada para outros reproduzirem o organismo vivo para fins de pesquisa e comercial, sendo essa última finalidade exercida após a expiração da patente ${ }^{25}$.

\subsection{Moralidade e Patenteamento das Invenções Biotecnológicas}

Além das questões atreladas aos requisitos de patenteabilidade, existe um grupo de argumentos de natureza ideológica e contrário ao patenteamento de invenções biotecnológicas, que vem sendo apontado nos últimos 50 anos, e que se acredita ter tido muita influência no final do século XX, especialmente nos anos 80 e $90^{26}$.

Dentre eles, está a noção religiosa baseada na obrigação do homem em preservar e respeitar a integridade da natureza e as criações de Deus e não atuar como criador de novas espécies de organismos vivos. Essa criação seria uma contravenção às leis divinas e uma usurpação aos materiais orgânicos fornecidos por Deus para a reprodução e evolução das espécies.

vivos, foi revertida pela Court of Customs and Patent Appeals e reacendeu as discussões sobre o patenteamento de coisas inanimadas, mesmo com o Ato de Patente de Planta de 1930 Id. Pág. 148-151. 24 . Id. Pág. 156-157. BELCHER, Brian e HAWTIN, Geoffrey. A Patent on Life. Ownership of Plants and Animal Research. International Development Research Centre (IDRC). Ottawa. 1991. Págs.16-20. 25 A iniciativa de alguns países, como os Estados Unidos, em permitir o depósito de amostras em centros depósitos como uma forma de suprir o requisito da divulgação deu ensejo ao Tratado de Budapeste sobre o Reconhecimento Internacional do depósito de Microrganismos para Efeitos do Procedimento em Matéria de Patentes. Esse tratado foi assinado em Budapeste, em 28/07/1977, e alterado em 26/09/1980. O tratado é administrado pela Organização Mundial da Propriedade Intelectual (OMPI) e conta atualmente com 75 países signatários. O Brasil não é membro do referido Tratado. Disponível em http://www.wipo.int/treaties/es/text. jsp?file_id=283785. Acesso em 23 de agosto de 2016.

26 CRESPI, R. Stephen. What's immoral in Patent Law. TIBTECH. Vol. 10 (november). 1992. Págs. 375-378. 
Os principais argumentos religiosos encontram-se compilados na obra de Brian Belcher, que abordou as discussões ocorridas no Canadá nos anos 80 e retratou que as oposições de caráter religioso se centraram, principalmente, nas técnicas de DNA recombinante em que parte do gene humano/animal/vegetal é isolado e clonado em outro ser vivo para alcançar resultados específicos e criar novas espécies ${ }^{27}$.

Reconhece-se a influência desse argumento para a interpretação e construção do regramento patentário às invenções biotecnológicas de diversos países, sendo notória a Lei da Propriedade Industrial brasileira (Lei n ${ }^{\circ}$ 9.279, de 14 de maio de 1996, ou LPI). Mesmo sendo classificadas como invenções tecnológicas, as partes e/ ou todo de seres vivos são expressamente vedados de patenteamento pela referida lei federal, exceto os microrganismos transgênicos.

Tais restrições impostas pelo art. 18 são baseadas em conceitos políticos e filosóficos presentes à época da promulgação da LPI, que, no caso do inc. III, dizia respeito às controvérsias religiosas sobre a biotecnologia ${ }^{28}$.

Conforme apontado por Belcher ${ }^{29}$, os valores de justiça e equidade andam pari passu com os argumentos religiosos e morais, pois o argumento da equidade baseia-se na injustiça em garantir-se a propriedade a uma única pessoa de um ser vivo, produto natural da humanidade, em contínua evolução por milhões de anos. A questão da equidade, nos anos 80, relacionou-se essencialmente nos países subdesenvolvidos, em grande parte, ao temor de controle dos recursos genéticos de plantas pelos países desenvolvidos, o que afetaria a competitividade das pesquisas nos países subdesenvolvidos baseadas na manipulação genética de seres vivos,

27 BELCHER, Brian e HAWTIN, Geoffrey. A Patent on Life. Ownership of Plants and Animal Research. International Development Research Centre (IDRC). Ottawa. 1991. Pág. 20-22.

28 Entende-se que a interpretação ao inc. III do Parágrafo Único do art. 18 da Lei 9.279/96 deve ser restritiva, seguindo os ditames filosóficos existentes à época de sua análise e não mais prevalecentes atualmente. Ainda, a forma abrangente disposta no art. 18 e, também, no art. 10, em contrapartida à interpretação restrita ditada pelas regras da hermenêutica, cria uma lacuna na lei em relação aos diversos detalhes no campo da biotecnologia, o que tem permitido que os examinadores do INPI flexibilizem, de alguma forma, a aplicação da lei da propriedade industrial. Tanto é assim que os vetores (vírus ou plasmídeos) enquadrados como elementos genéticos são aceitos como objeto de patenteamento.

29 BELCHER, Brian e HAWTIN, Geoffrey. A Patent on Life. Ownership of Plants and Animal Research. International Development Research Centre (IDRC). Ottawa. 1991. Págs. 21-24. além do elevado pagamento de royalties pelo uso dessas tecnologias ${ }^{30}$. Esse argumento foi influente na restrição de uma proteção maior aos inventos da biotecnologia nos países subdesenvolvidos ${ }^{31}$.

\subsection{Aspectos Gerais do Caso Chakrabarty - Nova Vida para as Patentes de Organismos}

As diversas discussões existentes nos Estados Unidos sobre o patenteamento de seres vivos foram dissipadas largamente por 2 (duas) decisões emitidas em junho de 1980 que abordaram as invenções biotecnológicas. As decisões foram o Caso Chakrabarty ${ }^{32}$ e o Caso Rohm\& Haas Co. ${ }^{33}$ pela Suprema Corte dos Estados Unidos. Ambas tiveram impacto importante no convencimento da doutrina jurídica quanto a patenteamento de seres vivos, sendo que a decisão do Caso Chakrabarty foi mais emblemática.

O Caso Chakrabarty representou verdadeiro direcionamento paradigmático no tocante ao patenteamento de seres vivos, vez que consolidou o entendimento quanto à possibilidade dessa proteção, desde que enquadrados como produto ou composição de matéria manipulada pelos seres humanos. Neste caso, discutiu-se a possibilidade de patenteamento de uma bactéria do gênero Pseudomonas que, geneticamente alterada, apresentaria dois ou mais plasmídios geradores de energia, capazes de consumir petróleo bruto em águas marinhas, ou seja, a bactéria era capaz de consumir este óleo em menor tempo, portanto mais eficaz para casos de desastres ambientais, por exemplo.

A decisão partiu da análise do Título 35 do U.S.C. 101 determinando que o intérprete da lei não deveria criar limitações à patente não expressas pelo legislador, visto que os termos utilizados (manufacture, composition of matter e any) indicariam um escopo de interpretação

30 CESAR, Jasiel. Alguns Aspectos Problemáticos do Patenteamento de Microorganismos. Artigo apresentado na VII Reunião da Federação de Sociedades de Biologia Experimental - FAESBE - realizada em Caxambu, de 26/29 de agosto de 1992 em Mesa Redonda intitulada Política de Ciência: Marcas e Patentes.

31 SMITH, Richard. Protection of Biotechnology Under Mexico's Industrial Property Law: Under Mexico's Industrial Prperty law: Can El Raton de Harvard Speak Spanish? 12 Biotechnology Law Report. Number 5 (1993). Págs. 529-535.-

32 Diamond v. Chakrabarty. 100 S. Ct. 2204 (1980)

33 Dawson Chemical Co. v. Rohm \& Hass Co. 100 St. Ct. 2601 (1980). Acredita-se que esse caso não teve repercussão pelas discussões centrarem-se na patentabilidade de um novo método de destruição de ervas daninhas. O Caso Chakrabarty focou na proteção de nova espécie de vida derivada da inserção genética de um ser vivo em outro. 
ampla. A decisão ressaltou que "tudo o que está abaixo do sol pode ser patenteado" desde que haja a engenhosidade humana. A bactéria de Chakrabarty não ocorria naturalmente, portanto, não seria um produto da natureza, mas, sim, da inventividade do homem.

Pode-se, então, presumir que o Caso Chakrabarty efetivou o patenteamento de produtos extraídos, de alguma forma, da natureza, mas, tais produtos deverão observar os requisitos de patenteabilidade, analisando-se a similaridade na estrutura e na utilidade entre a reivindicação e o que é encontrado na natureza ${ }^{34}$. Mais ainda, ficou determinado que os produtos da natureza, sem qualquer intervenção humana, não seriam bens jurídicos passíveis de patenteamento.

Quanto aos produtos isolados e purificados, estes atendiam aos dois requisitos, já que não se apresentavam na forma isolada na natureza e possuíam propriedades úteis não ocorrentes na sua forma natural.

Tais argumentos técnicos do Caso Chakrabarty foram relevantes para afastar tentativas de exclusão de patenteabilidade baseadas em razões essencialmente baseadas em políticas públicas, moralidade, religiosidade, dentre outras. As análises devem estar relacionadas aos requisitos de patenteabilidade e enquadramento dos desenvolvimentos tecnológicos em invenções ou não ${ }^{35}$.

34 Quanto ao posicionamento do USPTO, no que se refere às sequências genéticas isoladas, tinha-se que a purificação fazia surgir uma diferença transformadora da utilidade entre o produto novo e o seu precursor natural, além da diferença estrutural. Veja BEAUCHAMP, Christopher. Patenting nature: a problem of history. In 16 Stanford Technology Law Review, 257 (2013). Disponível em: http://papers.ssrn.com/sol3/papers.cfm?abstract_id=2152105. Acesso em 30 de agosto de 2016. p. 306.

35 Veja o Artigo 27 do ACORDO SOBRE ASPECTOS DOS DIREITOS DE PROPRIEDADE INTELECTUAL RELACIONADOS AO COMÉRCIO (também denominado TRIPS), que proibiu discriminações quanto aos desenvolvimentos a serem protegidos, cabendo mencionar o seguinte texto: "1. Sem prejuízo do disposto nos parágrafos 2 e 3 abaixo, qualquer invenção, de produto ou de processo, em todos os setores tecnológicos, será patenteável, desde que seja nova, envolva um passo inventivo e seja passível de aplicação industrial. (...) 2. Os Membros podem considerar como não patenteáveis invenções cuja exploração em seu território seja necessária evitar para proteger a ordem pública ou a moralidade, inclusive para proteger a vida ou a saúde humana, animal ou vegetal ou para evitar sérios prejuízos ao meio ambiente, desde que esta determinação não seja feita apenas por que a exploração é proibida por sua legislação. 3. Os Membros também podem considerar como não patenteáveis: a) métodos diagnósticos, terapêuticos e cirúrgicos para o tratamento de seres humanos ou de animais; b) plantas e animais, exceto micro-organismos e processos essencialmente biológicos para a produção de plantas ou animais, excetuando-se os processos não-biológicos e microbiológicos. Não obstante, os Membros con-

\section{A Contribuição do Caso Myriad ao Patenteamento de Invenções BioteCNOLÓgICAS}

Em 13 de junho de 2013, a Suprema Corte emitiu decisão de extrema importância para a indústria da biotecnologia, sedimentando o entendimento de que não é possível a concessão de patentes ou o patenteamento de sequências genéticas meramente isoladas, entendimento este que impacta na compreensão de todos os produtos isolados ou purificados.

Neste emblemático caso, as patentes da Myriad, importante companhia farmacêutica, sobre as sequências isoladas BRCA 1 e BRCA 2 (relativas ao câncer de mama e ovário), obtidas com base na prática norte-americana até então vigente, foram questionadas por associações civis libertárias. O argumento foi no sentido de não serem verdadeiras invenções, mas, descobertas, além de prejudicar o desenvolvimento de pesquisas que poderiam salvar vidas.

De plano, deve-se esclarecer a importância das sequências BRCA 1 e BRCA 2, isto porque referem-se a mutações que podem significar uma predisposição ao câncer de mama e/ou ovário; daí a busca pela sua proteção, para obstar, inclusive, testes genéticos ${ }^{36}$.

Uma mutação é definida como qualquer alteração na sequência de bases ou rearranjo do material genético. Estas mutações podem ser deletérias ou patogênicas (quando causam doenças). Daí a importância do estudo e avanços nesta área. "A identificação de mutações e a compreensão de como estas levam à variabilidade fenotípica entre as pessoas, incluindo a manifestação de doenças, é um dos principais desafios da genética molecular humana ${ }^{37 "}$.

A susceptibilidade ao câncer de mama ocorre por

cederão proteção a variedades vegetais, seja por meio de patentes, seja por meio de um sistema sui generis eficaz, seja por uma combinação de ambos."

36 Note-se que, diferentemente de outros empresários detentores de patentes sobre outras sequências genéticas isoladas, que não exerciam controle efetivo sobre seus direitos e concediam licenças não exclusivas, de forma gratuita para terceiros, a Myriad exerceu seus direitos sobre tais sequências de forma agressiva e impediu que outros empresários e/ou médicos oferecessem o teste sobre as sequências ou mesmo realizassem pesquisas. Esta conduta agressiva provocou reação no mercado para revogação dos direitos patentários.

37 PASSOS-BUENO, Maria Rita. MOREIRA, Eloísa de Sá. Ferramentas Básicas da Genética Molecular Humana. In MIR, Luís (org.). Genômica. São Paulo, SP: Atheneu, 2004. pp. 45. 
herança, tanto paterna quanto materna, e o risco aumenta de acordo com o número de indivíduos afetados na família. Indivíduos com histórico familiar de neoplasias e mutações nos genes de células germinativas BRCA1 e BRCA2 apresentam alto risco de desenvolver neoplasias de mama e ovário respectivamente. A média da população feminina norte-americana tem de $12 \mathrm{a}$ $13 \%$ de risco de desenvolver o câncer de mama, mas as mulheres com mutações genéticas podem ter este risco aumentado de 50 a $80 \%$ para o câncer de mama e entre 20 a 50\% para o câncer de ovário ${ }^{38}$. Diante da importância social de tais sequências genéticas paro controle dos casos de câncer de mama e ovário na população, colocou-se em questão o monopólio da Myriad.

Desta forma, a American Civil Liberties Union (ACLU) e a Public Patent Foundation (PPF) questionaram as patentes sobre o BRCA 1 e BRCA 2 na Corte Distrital Sul de Nova Iorque, que entendeu não serem patenteáveis as reivindicações da Myriad. Assim, houve recurso à Corte de Apelações do Circuito Federal, que entendeu serem patenteáveis as sequências isoladas. Após recurso à Suprema Corte, solicitando reexame do caso à Corte de Apelações, que manteve a sua decisão, houve novo peticionamento, em 25 de setembro de $2012^{39}$, junto à Suprema Corte para que se manifestasse sobre a possibilidade de patenteamento de sequências genéticas humanas, mediante petição de writ of certiorari, que, em 30 de novembro de 2012, foi admitida somente quanto à questão: "são os genes humanos patenteáveis? "

A Suprema Corte, por maioria, decidiu, então, pela invalidação das reivindicações das patentes da Myriad relativas às sequências genéticas puramente isoladas com base no fundamento de que seriam produtos encontrados na natureza, permanecendo válidas as reivindicações relativas ao cDNA (DNA complementar).

38 MOREIRA-FILHO, Carlos Alberto. Medicina Genômica e prática clinica. In MIR, Luís (org.). Genômica. São Paulo, SP: Atheneu, 2004. pp. 195-205.

39 Importante salientar que, em termos processuais, após a decisão da Corte de Apelação, em julho de 2011, houve o primeiro peticionamento à Suprema Corte, que acabou por revogar a decisão do Circuito Federal, determinando que o caso fosse revisto à luz da decisão em Mayo Collaborative Services v. Prometheus Laboratories Inc. Assim, o caso foi revisto, levando-se em consideração tal decisão, sendo que, quanto às sequências genéticas propriamente ditas, tal precedente não significaria maior relevância, já que mais específico quanto ao método discutido no caso, já mencionado. Após esta segunda decisão, houve novo peticionamento à Suprema Corte, para que decidisse de forma especifica sobre o caso, em setembro de 2012.
A Suprema Corte esclareceu que algumas questões não foram submetidas à sua apreciação. Neste sentido, o juiz Thomas ${ }^{40}$ :

It is important to note what is not implicated by this decision. First, there are no method claims before this Court. Had Myriad created an innovative method of manipulating genes while searching for the BRCA1 and BRCA2 genes, it could possibly have sought a method patent. But the processes used by Myriad to isolate DNA at the time of Myriad's patents "were well understood, widely used, and fairly uniform insofar as any scientist engaged in the search for a gene would likely have utilized a similar approach," 702 F. Supp. $2 \mathrm{~d}$, at 202-203, and are not at issue in this case.

Similarly, this case does not involve patents on new applications of knowledge about the BRCA1 and BRCA2 genes. Judge Bryson aptly noted that, "[a]s the first party with knowledge of the [BRCA1 and BRCA2] sequences, Myriad was in an excellent position to claim applications of that knowledge. Many of its unchallenged claims are limited to such applications." 689 F. 3d, at 1349.

Nor do we consider the patentability of DNA in which the order of the naturally occurring nucleotides has been altered. Scientific alteration of the genetic code presents a different inquiry, and we express no opinion about the application of $\$ 101$ to such endeavors. We merely hold that genes and the information they encode are not patent eligible under $\$ 101$ simply because they have been isolated from the surrounding genetic material. (grifos nossos)

Em verdade, a Suprema Corte utilizou-se de vocabulário bastante específico para resumir as questões em jogo. Afirmou ${ }^{41}$ que a Myriad teria obtido diversas patentes após a descoberta da localização precisa e sequenciamento das mutações de BRCA 1 e BRCA 2, que determinam um aumento dramático no risco de desenvolvimento de câncer de ovário e mama. Tal conhecimento permitiu que a Myriad desenvolvesse testes laboratoriais aplicáveis ("testes médicos úteis") à detecção de tais mutações. Se consideradas válidas, as patentes concederiam ao seu detentor o direito exclusivo de isolar os genes BRCA 1 e BRCA 2 de um indivíduo, bem como dariam à Myriad o direito exclusivo de criar sinteticamente o cDNA do BRCA.

40 Opinião da Corte no Caso Myriad, página 17. Disponível em: http://supreme.justia.com/cases/federal/us/569/12-398. Acesso em 02 de setembro de 2016.

41 SUPREME COURT OF THE UNITED STATES. Association for Molecular Pathology et al. v. Myriad Genetics Inc. et al. n. 12-398. Syllabus. Disponível em: https://www.supremecourt.gov/ opinions/12pdf/12-398_1b7d.pdf. Acesso em 02 de setembro de 2016. 
Assim, em razão do não atendimento ao parágrafo 101, do Título 35, do U.S. Code ${ }^{42}$, ou seja, por serem verdadeiros produtos da natureza, carecendo de inventividade, as sequências genéticas isoladas não seriam patenteáveis.

Apesar de a ACLU e a PPF terem argumentado que tais patentes impediriam a inovação, em razão da vedação à realização de pesquisas; e limitariam as opções de testes dos pacientes portadores de câncer, violando, inclusive, a Primeira Emenda da Constituição dos Estados Unidos da América ${ }^{43}$ (1st Amendment) por bloquearem a pesquisa científica sobre a sequência isolada, já que seria uma patente de informação pura, isto não foi avaliado pela Suprema Corte.

A Myriad, por outro lado, argumentou que as sequências genéticas isoladas seriam passíveis de proteção com base no entendimento de que seriam compostos químicos. Desta feita, a sequência, após o processo de isolamento, apresentaria características diferentes daquelas encontradas no corpo humano. Ainda, acrescentou que tais patentes promovem a inovação no campo da biotecnologia, em especial quanto à engenharia genética, na medida em que, ao serem concedidas as patentes, tornam público o conhecimento sobre estas, fomentando que não sejam mantidas como segredo de negócio.

O entendimento do USPTO anterior a esta decisão era de que a proteção patentária somente seria possível quando houvesse alteração substancial dos produtos que ocorrem naturalmente. Desta forma, o isolamento da sequência genética caracterizaria esta alteração substancial, configurando verdadeira invenção.

A principal base desta decisão da Suprema Corte deu-se em razão da aplicação da teoria da exceção à patenteabilidade dos produtos da natureza, forjada, em razão do sistema da common law, com base nos precedentes judiciais, mas não com base em preceitos éticos, morais ou religiosos.

Antes de se adentrar na seara dos precedentes, deve-se esclarecer que o sistema de patentes norte-america-

4235 U.S.C. \$101 35 U.S.C. 101 Inventions patentable: Whoever invents or discovers any new and useful process, machine, manufacture, or composition of matter, or any new and useful improvement thereof, may obtain a patent therefor, subject to the conditions and requirements of this title.

43 "Congress shall make no law respecting an establishment of religion, or prohibiting the free exercise thereof; or abridging the freedom of speech, or of the press; or the right of the people peaceably to assemble, and to petition the Government for a redress of grievances". no se funda no artigo I, seção 8, cláusula 8 da Constituição dos Estados Unidos ${ }^{44}$. O Título 35 do Código dos Estados Unidos (United States Code) instituiu o Ato de Patentes de 1952 (Patent Act).

Assim, os requisitos básicos para a concessão da patente, que encontram sua base nestes documentos, são: novidade (\$102), utilidade (\$101), não-obviedade (\$103) (ou atividade inventiva) ${ }^{45}$ e suficiência descritiva (\$112). Nos termos do Título 35 do Código dos Estados Unidos, em seu $\$ 101$ :

\begin{abstract}
aquele que inventa ou descobre qualquer novo e útil processo, máquina, manufatura, ou composição de matérias, ou qualquer novo e útil aperfeiçoamento, poderá obter uma patente, sujeita às condições e requisitos deste título.
\end{abstract}

A partir de precedentes judiciais norte-americanos ${ }^{46}$ que foram citados no Caso Myriad, algumas premissas podem ser extraídas quanto à exceção ao patenteamento de produtos da natureza: (i) um produto idêntico ao preexistente derivado de uma nova fonte não atende ao requisito de novidade; (ii) o produto meramente extraído e que não apresenta nenhuma alteração não poderá ser patenteado (requisito da alteração estrutural necessária); (iii) a substância isolada deve ser bem mais útil do que a sua forma natural.

Dois casos são mencionados como de extrema importância para a tomada de decisão pela Suprema Corte: o Caso Parke-Davis (Parke-Davis \& Co. v H. K. Mulford Co. CCSDNY 189 F 95; 1911 U.S. App LEXIS 5245), que serviu de base para as primeiras patentes sobre se-

44 ESTADOS UNIDOS DA AMÉRICA. Constituição Federal. Art. I, §8, cl. 8. O Congresso terá o poder para "promover o Progresso da Ciência e Artes úteis, assegurando por tempo limitado aos autores e inventores o direito exclusivo sobre suas respectivas escritas e descobertas".

4535 U.S. Code (U.S.C.) \$103: “A patente poderá não ser concedida caso a invenção não seja exposta ou descrita na forma da seção 102 deste título, se as diferenças entre o objeto sujeito a patente e a arte anterior sejam de forma que o todo tenha sido óbvio ao tempo da invenção para uma pessoa que tivesse habilidades comuns naquela arte à qual pertence o objeto a ser patenteado".

46 (i) Cochrane v. Badische Anilin \& Soda Fabrik, 111 U.S. 293 (1884); (ii) Decisions of the Comissioner of Patents. Ex Parte Latimer, decidido em 12 de março de 1889, 46 O.G. 1638. (iii) Circuit Court, N. D. New York. Blumenthal v. Burrell et al. 10 de outubro de 1890. (iv) Kuehmsted v. Farbenfabriken of Eberfeld Co. 171 F. 887,890 (CCNDIL, 1909). (v) Parke-Davis \& Co. v H. K. Mulford Co. CCSDNY 189 F 95; 1911 U.S. App LEXIS 5245. (vi ) Funk Brothers Seed Co. v. Kalo Inoculant Co. 333 U.S. 127 (1948). (vii) Merck \& Co. v. Olin Mathieson Chemical Corp. 253 F.2D 156 (4th. Circuit 1958). 
quências genéticas, na década de $90^{47}$, e o Caso Chakrabarty, que em muito influenciou para que o USPTO adotasse uma postura mais liberal na concessão de patentes sobre organismos vivos e dirimisse argumentos contrários ao patenteamento de seres vivos, principalmente aqueles relacionados aos requisitos de patenteabilidade.

No Caso Parke-Davis, discutiu-se acerca da substância adrenalina ${ }^{48}$, um produto que consiste no princípio ativo das glândulas suprarrenais em forma branca, sólida e cristalina, criado por Takamine, que teve sua patente requerida em 1900. Em princípio, o pedido foi rejeitado pelo USPTO, com base na teoria dos produtos da natureza. Todavia, argumentaram os requerentes da patente que, se o produto existia na natureza, certamente ele não teria a forma branca, sólida e cristalina. Ou seja, havia uma diferença estrutural entre o produto encontrado na natureza e o produto sobre o qual se solicitava a proteção patentária.

Diante da negativa ao patenteamento pelo USPTO, os requerentes alteraram a sua reivindicação, descrevendo-a como uma substância possuindo as características e reações das glândulas suprarrenais ${ }^{49}$, ressaltando que seria possível o patenteamento, com base em Ex parte Latimer $^{50}$, caso o inventor adicionasse uma nova qualidade ou função que a substância natural não possuísse na sua condição natural, sendo que a substância do requerente era estável e não deteriorava - ou seja, o requerente fundamentou seu pedido na comprovação

47 BEAUCHAMP, Christopher. Patenting nature: a problem of history. In 16 Stanford Technology Law Review, 257 (2013). Disponível em: http://papers.ssrn.com/sol3/papers.cfm?abstract_ $\mathrm{id}=2152105$. Acesso em 30 de agosto de 2016. p. 305.

48 Em 1894, pesquisadores ingleses verificaram o efeito de aumento da pressão arterial obtido a partir de um extrato da glândula adrenal de animais. Em 1897, um pesquisador da Johns Hopkins produziu uma substância cristalina que acreditava ser o princípio ativo daquele extrato, na sua forma purificada, chamando-a de epinefrina. Neste ínterim, um pesquisador austríaco isolou um composto similar chamado de suprarrenina. Takamine, um pesquisador japonês, em 1900, conseguiu êxito em isolar o princípio da epinefrina, com a técnica de pecipitação em amônia, obtendo, enfim, a adrenalina. In BEAUCHAMP, Christopher. Patenting nature: a problem of history. In 16 Stanford Technology Law Review, 257 (2013). Disponível em: http://papers.ssrn.com/sol3/papers.cfm?abstract_id=2152105. Acesso em 15 de agosto de 2016. p. 285-286.

49 BEAUCHAMP, Christopher. Patenting nature: a problem of history. In 16 Stanford Technology Law Review, 257 (2013). Disponível em: http://papers.ssrn.com/sol3/papers.cfm?abstract_ $\mathrm{id}=2152105$. Acesso em 30 de agosto de 2016. p. 288.

50 Decisions of the Comissioner of Patents. Ex Parte Latimer, decidido em 12 de março de 1889, 46 O.G. 1638. do requisito de alteração funcional, nas características de permanência e estabilidade. Finalmente, em 1903, a patente $^{51}$ foi concedida. Ou seja, a estabilidade era suficiente para caracterizar uma nova função.

Todavia, em 1911, no Caso Parke-Davis ${ }^{52}$ o questionamento não se deu com foco na teoria dos produtos da natureza ${ }^{53}$, mas, sim, com base no fato de que a substância de Takamine não seria nova por ter sido antecipada por outros cientistas em pesquisas anteriores, argumento este que foi rejeitado pelo juiz Hand, tendo em vista que a substância de Takamine se diferenciava das anteriores exatamente por pretender e conseguir excluir o sal na sua purificação. Note-se que, neste caso, a discussão baseou-se no fato de que a substância "Adrin", comercializada pela H. K. Mulford Co., infringia patentes licenciadas à Parke-Davis \& Co., que comercialiazava produto similar sob a marca "Adrenalin" 54 .

Ressaltou Hand que, mesmo que houvesse apenas um extrato, sem qualquer alteração, não havia precedente para que tal produto não fosse patenteável, tendo em vista a interpretação ampla na concessão, acrescentando que o produto tinha um novo valor terapêutico e comercial $^{55}$. Ou seja, em verdade, apesar de reiteradamente citado no Caso Myriad, o Caso Parke-Davis, em si, não se baseia na análise da exceção ao patenteamento de produtos da natureza.

Deve-se ressaltar o já mencionado Caso Chakrabarty, que consolidou o entendimento quanto à possibilidade de patenteamento de seres vivos, desde que se enquadrassem como produto ou composição de matéria.

Quanto ao posicionamento do USPTO, no que se refere às sequências genéticas isoladas, tinha-se que a

51 Patente n. 730176. Outras patentes adjacentes relacionadas à substância: Patentes n. 730175 e 753177.

52 US COURTS. Parke-Davis \& Co. v H. K. Mulford Co. CCSDNY 189 F 95; 1911 U.S. App LEXIS 5245. Disponível em: http:/ / www.pubpat.org/assets/files/brca/mats/Parke-Davis, $\% 20189 \% 20$ Fed\%2095\%20(1911).pdf. Acesso em 29 de agosto de 2016.

53 CROUCH, Dennis. Guest Post: Myriad Misunderstandings of Parke-Davis v. Mulford. Disponível em: http://patentlyo.com/patent/2012/05/myriad-parke-davis.html. Acesso em 29 de agosto de 2016.

54 HARKNESS, Jon M. Dicta on Adrenalin(e): Myriad problems with Learned Hand's Product-of-Nature Pronouncements in ParkeDavis v. Mulford. Disponível em: https://works.bepress.com/jon_ harkness/1/. Acesso em 20 de agosto de 2016.

55 BEAUCHAMP, Christopher. Patenting nature: a problem of history. In 16 Stanford Technology Law Review, 257 (2013). Disponível em: http://papers.ssrn.com/sol3/papers.cfm?abstract_ $\mathrm{id}=2152105$. Acesso em 30 de agosto de 2016. p. 292. 
purificação fazia surgir uma diferença transformadora da utilidade entre o produto novo e o seu precursor natural $^{56}$, além da diferença estrutural.

Pode-se, então, presumir que é possível o patenteamento de produtos extraídos, de alguma forma, da natureza, mas tais produtos deverão observar os requisitos normais de patenteabilidade, analisando-se a similaridade na estrutura e na utilidade entre a reivindicação e o que é encontrado na natureza.

Assim, entendia-se que os produtos isolados e purificados atendiam aos dois requisitos, já que não se apresentavam na forma isolada na natureza e possuíam propriedades úteis não ocorrentes na sua forma natu$\mathrm{ral}^{57}$. Todavia, este entendimento foi questionado com a decisão no Caso Myriad, de forma que o critério da novidade pela maior utilidade foi, ao menos para os produtos isolados, superado, não havendo de se presumir a maior utilidade pelo simples isolamento ou purificação, havendo de ser feita a análise em concreto.

A Suprema Corte entendeu que a principal contribuição da Myriad foi revelar a localização precisa dos genes BRCA1 e BRCA2, mas não havia uma ação com características marcantemente diferentes das encontradas na natureza. A Myriad teria descoberto um importante e útil gene, mas a descoberta, mesmo que inovadora, não satisfaz, por si, os requisitos ao patenteamento. Ainda, o exaustivo processo de tal descoberta não atende aos requisitos de patenteabilidade, da mesma forma, porque já conhecido e utilizado vastamente pela comunidade científica.

Diferentemente, o cDNA, DNA sintético que contém somente as porções codificantes, ou seja, os éxons, por não ocorrer naturalmente, poderia receber a proteção, não sendo invalidadas reivindicações com base no cDNA, salvo quando se tratar de sequência curta de cDNA, por não se diferenciar do DNA natural de forma substancial (quando não houvesse íntrons a serem removidos). De toda forma, note-se que a Myriad possui extrema vantagem competitiva com relação aos seus testes sobre as sequências do BRCA 1 e BRCA 2, tendo

56 BEAUCHAMP, Christopher. Patenting nature: a problem of history. In 16 Stanford Technology Law Review, 257 (2013). Disponível em: http://papers.ssrn.com/sol3/papers.cfm?abstract_ $\mathrm{id}=2152105$. Acesso em 30 de agosto de 2016. p. 306.

57 BEAUCHAMP, Christopher. The pure thoughts of Judge Hand: A historical note on the patenting of nature. Disponível em: http://www.law.nyu.edu/sites/default/files/ECM_PRO_071307. pdf. Acesso em 30 de agosto de 2016. p. 2. em vista a extensa base de dados formada com base nos seus pacientes anteriormente testados ${ }^{58}$.

\section{Materiais Genéticos e o Impacto da Decisão do Caso Myriad no Patenteamento DE INVENÇÕES TECNOLÓGICAS}

De uma forma geral, quando um organismo ativa um gene, este tem a sua sequência de nucleotídeos lida e copiada no processo de transcrição. Para que seja iniciada a transcrição, as proteínas de histona devem ser quebradas e os filamentos de DNA separam-se na bolha de transcrição.

Neste momento, a cópia do material genético é sintetizada no RNA. Em sequência, a estrutura do RNA é modificada, incluindo-se a remoção dos íntrons, para que seja criado o mRNA. A sequência copiada, então, produz uma proteína a partir do processo de tradução ${ }^{59}$. Durante a tradução, os códons do mRNA são lidos de forma que um aminoácido específico é incorporado na proteína originada a partir da sequência de nucleotídeos dentro daquele códon. O mRNA, durante a tradução ou síntese proteica, dirige a incorporação de aminoácidos da proteína nascente por meio dos seus códons.

Na criação do cDNA, aplica-se a enzima transcriptase reversa sobre o segmento de mRNA e, a partir de processos completamente naturais, tem-se a síntese de um RNA e, após, o cDNA. Observe-se que as sequências são complementares entre si.

Quanto às sequências genéticas isoladas e/ou purificadas, a primeira argumentação possível é de que há uma transformação da molécula de DNA por intervenção humana em algo estruturalmente e funcionalmente diferente do correspondente natural. Isso porque a sequência desejada é retirada do restante do cromossomo, rompendo-se as ligações covalentes entre o cromossomo e o seu DNA, sendo que tais alterações químicas

58 GREELY, Henry T e SHERKOW, Jacob S. The future of gene patents and the implications for medicine. JAMA Internal Medicine. Volume 173, Number 17. Stanford University: September 23, 2013. Disponível em: http://papers.ssrn.com/sol3/papers.cfm?abstract_ id $=2325679 \& \mathrm{rec}=1 \&$ srcabs $=2499885 \& \mathrm{alg}=1 \& \mathrm{pos}=4$. Acesso em 02 de setembro de 2016.

59 BOWMAN, Andrew. Genes 101: Are human genes patentable subject matter?. XVIII RICH. J. L. \& TECH. 15. Disponível em: http://jolt.richmond.edu/v18i4/article15.pdf. Acesso em 02 de setembro de 2016. p. 17. 
promovem a criação de uma nova molécula não existente na natureza. As sequências isoladas não possuem as regiões regulatórias, portanto, são quimicamente diferentes, com estrutura distinta. Ainda, há a diferença funcional, na medida em que proporcionam um novo uso às sequências naturais, que não podem ser manipuladas e controladas da mesma forma.

Andrew Bowman propõe que sejam analisadas tanto as diferenças estruturais quanto informacionais ${ }^{60}$, para que se respeite a exceção judicial ao patenteamento dos produtos da natureza. Para ele, deve-se adotar a postura da totalidade das circunstâncias (Totality-of-the-circumstances approach). Assim, surgem duas perspectivas: uma perspectiva química e outra biológica.

Sob a perspectiva química, considera-se apenas a análise da estrutura molecular. Neste aspecto, há, geralmente, clara diferença entre os materiais genéticos, já que, normalmente, os casos envolvem a quebra química. Sob a perspectiva biológica, deve-se analisar a informação que a estrutura revela. Neste caso, não haveria diferença substancial entre o DNA natural e o DNA isolado, já que o conteúdo informacional seria mantido. $\mathrm{Na}$ opinião de Bowman ${ }^{61}$, para que houvesse diferença, a sequência de DNA isolado deveria codificar para uma proteína suficientemente diferente daquela encontrada na natureza. A opinião da juíza Moore ${ }^{62}$, do Circuito Federal, no Caso Myriad, indicou claramente este raciocínio, já que identificou que o DNA isolado serve aos mesmos fins concebidos pela natureza.

Todavia, quanto ao cDNA, para Bowman ${ }^{63}$, seria possível o patenteamento, o que está de acordo com a decisão da Suprema Corte, apesar de, no fim, codificar para a mesma proteína. Afirma que o mRNA maduro passa por significativas mudanças durante a transcrição, mais especificamente no que se refere à remoção dos íntrons.

60 BOWMAN, Andrew. Genes 101: Are human genes patentable subject matter?. XVIII RICH. J. L. \& TECH. 15. Disponível em: http://jolt.richmond.edu/v18i4/article15.pdf. Acesso em 02 de setembro de 2016. p. 18.

61 BOWMAN, Andrew. Genes 101: Are human genes patentable subject matter?. XVIII RICH. J. L. \& TECH. 15. Disponível em: http://jolt.richmond.edu/v18i4/article15.pdf. Acesso em 02 de setembro de 2016. p. 22.

62 Disponível em: http://www.cafc.uscourts.gov/sites/default/ files/opinions-orders/10-1406.pdf. Acesso em 02 de setembro de 2016.

63 BOWMAN, Andrew. Genes 101: Are human genes patentable subject matter?. XVIII RICH. J. L. \& TECH. 15. Disponível em: http://jolt.richmond.edu/v18i4/article15.pdf. Acesso em 02 de setembro de 2016. p. 25.
Quanto ao cDNA, como este é sintetizado a partir do mRNA, contém apenas as sequências codificantes, ou seja, os éxons, diferenciando-se de forma estrutural da sequência natural ou isolada, que contêm ambos os íntrons e éxons ${ }^{64}$.

O cDNA, então, funciona como um mRNA de dupla hélice, sendo mais estável in vitro. Todavia, esta situação é meramente transitória, já que, assim que colocado à utilização para pesquisa de genes ou sequências, por exemplo, é imediatamente quebrado, tornando-se uma estrutura de fita simples, igual ao mRNA.

Do ponto de vista hereditário, funciona como um mRNA, contendo a mesma informação genética. Bioquimicamente difere do mRNA apenas pela presença de ácido ribonucleico ao invés de ácido desoxirribonucleico e pela presença da base nitrogenada uracila ao invés da timina, presente no DNA.

Não se pode se pode negar a sua diferença estrutural, mas nada mais é que um mero desvio na codificação da proteína (diante da equivalência informacional), já que tanto o DNA cromossomial, quanto a sequência isolada, bem como a proteína codificada, seriam considerados produtos da natureza (sem intervenção humana), portanto, não passíveis de patenteamento.

Há a criação de um subterfúgio à impossibilidade de patenteamento do DNA, uma burla à exceção dos produtos da natureza, visto que o cDNA se sintetiza de acordo com as leis da natureza. No mais, o cDNA codifica para proteínas já existentes na natureza e a própria sequência que define o cDNA foi predeterminada pela natureza ${ }^{65}$.

Ainda, deve-se ressaltar que, da mesma forma que a sequência isolada, o cDNA é ferramenta básica da engenharia genética, impedindo, ao menos para o direito norte-americano, pesquisas com base naquele cDNA, o que releva argumentos baseados no impacto negativo

64 KHAN, Fazal; e KESSLER, Lindsay. Genomics Unbound: The scientific and legal case against patents based on naturally occurring DNA sequences. Nevada Law Journal vol. 13:668. Disponível em: http://digitalcommons.law.uga.edu/cgi/viewcontent. cgi? article $=1918 \&$ context $=$ fac_artchop. P. 678. Acesso em 02 de setembro de 2016.

65 KHAN, Fazal; e KESSLER, Lindsay. Genomics Unbound: The scientific and legal case against patents based on naturally occurring DNA sequences. Nevada Law Journal vol. 13:668. Disponível em: http://digitalcommons.law.uga.edu/cgi/viewcontent. cgi? article $=1918 \&$ context $=$ fac_artchop. P. 678. Acesso em 02 de setembro de 2016 
ao desenvolvimento científico e tecnológico.

Quanto ao DNA recombinante, a sua tecnologia funciona como uma técnica de copiar e colar sequências de DNA no interesse do cientista ${ }^{66}$. Assim, o cDNA é inserido em uma bactéria hospedeira para a transcrição em mRNA, que é traduzida na proteína almejada.

A tecnologia do DNA recombinante ( $\mathrm{rDNA}$ ) cria novas sequências de DNA a partir da junção de peças de DNAs de diferentes organismos. A principal diferença entre as moléculas de rDNA que ocorrem naturalmente das sintetizadas é que, nestas últimas, as alterações nas informações genéticas são predeterminadas e resultam de uma manipulação humana.

Por sua vez, a célula ou organismo hospedeiro poderá expressar este DNA estrangeiro, produzindo as proteínas desejadas, que não seriam produzidas caso o DNA não fosse alterado.

Assim, o rDNA, claramente, não se verifica na natureza, bem como sua sequência não é predeterminada por nenhuma lei da natureza ${ }^{67}$, de forma que sua criação requer o corte e a recombinação de sequências genéticas da maneira correta para que sejam operacionais no organismo hospedeiro. Argumenta-se que estas sequências de rDNA, por serem fruto de verdadeira engenhosidade, seriam passíveis de patenteamento.

Esss são as principais extrações que podem ser obtidas da decisão do caso Myriad e as influência mais impactantes nas jurisdições dos países, visto que o Sistema de Patente é determinado por 2 (dois) tratados internacionais: a Convenção da União de Paris de $1883^{68}$ e o Acordo TRIPS. ${ }^{69}$ Esses tratados determinam, de alguma

66 KHAN, Fazal; e KESSLER, Lindsay. Genomics Unbound: The scientific and legal case against patents based on naturally occurring DNA sequences. Nevada Law Journal vol. 13:668. Disponível em: http://digitalcommons.law.uga.edu/cgi/viewcontent. cgi? article $=1918 \&$ context $=$ fac $\_$artchop. P. 678. Acesso em 02 de setembro de 2016.

67 KHAN, Fazal; e KESSLER, Lindsay. Genomics Unbound: The scientific and legal case against patents based on naturally occurring DNA sequences. Nevada Law Journal vol. 13:668. Disponível em: http://digitalcommons.law.uga.edu/cgi/viewcontent. cgi?article $=1918 \&$ context $=$ fac_artchop. P. 678. Acesso em 04 de setembro de 2016.

68 Convenção da União de Paris de 1883 inserida no ordenamento brasileiro, por meio do Decreto $\mathrm{N}^{\mathrm{0}} 75.572$, de8 de abril de 1975. Disponível em http://www2.camara.leg.br/legin/fed/decret/1970-1979/decreto-75572-8-abril-1975-424105-publicacaooriginal-1-pe.html. Acesso em 04 de setembro de 2016.

69 Acordo sobre Aspectos dos Direitos de Propriedade Intelectual Relacionados ao Comércio (também denominado TRIPS), inseri- forma, um andamento uniforme das legislações dos países signatários, não obstante a preservação do Princípio do Tratamento Nacional, que outorga liberdade para cada país signatário tomar as decisões quanto ao patenteamento de uma invenção tecnológica

\section{Proteção Intelectual da Biotecnologia na Legislação Brasileira: O Homem Brincando de Deus ou Reserva de Mercado PARA OS EmpresáRIOS EM BIOTECNOLOGIA}

A legislação patentária brasileira parece não deixar margem para dúvidas, vedando a possibilidade do patenteamento das sequências genéticas isoladas, inclusive o genoma. Tal assertiva decorre da análise conjunta do art. 10, IX, e do item III do art. 18 da LPI.

O preceito constitucional nacional que fundamenta a propriedade industrial encontra-se insculpido no inciso XXIX, do artigo $5^{\circ}$, determinando que "a lei assegurará aos autores de inventos industriais privilégio temporário para sua utilização, bem como proteção às criações industriais, à propriedade das marcas, aos nomes de empresas e a outros signos distintivos, tendo em vista o interesse social e o desenvolvimento tecnológico e econômico do País". Esta cláusula final evidencia que os direitos relativos à propriedade industrial não derivam diretamente da Carta Constitucional, mas, sim, da lei ordinária, que só será constitucional na medida em que atender aos objetivos de (i) visar ao interesse social do país; (ii) favorecer o desenvolvimento tecnológico do país; e (iii) favorecer o desenvolvimento econômico do país ${ }^{70}$. Devemos transportar este valor da função social para o direito de propriedade industrial, em específico. O progresso técnico é alcançado, e a livre-concorrência, garantida, quando o sistema de patentes funciona (a) como promotor à atividade inventiva; (b) como incentivo à revelação das informações técnicas geradas para a produção da invenção pelo inventor a toda a coletividade, em razão da contribuição para o estado da técnica; e (c) como incentivo à difusão das invenções, havendo

do no ordenamento jurídico por meio do Decreto n. 1.355, de 30 de dezembro de 1994. Disponível em www.planalto.gov.br/ccivil_03/ decreto/antigos/d1355.htm. Acesso em 04 de setembro de 2016.

70 BARBOSA, Denis Borges. In DIAFÉRIA, Adriana. Patente de genes humanos e a tutela dos interesses difusos: o direito ao progresso econômico, científico e tecnológico. Rio de Janeiro: Lumen Juris, 2007. p. xxiii. 
um equilíbrio no desfrutamento dos direitos conferidos pela patente . $^{71}$.

Desta forma, quando a lei ordinária afastar da possibilidade de patenteamento determinada invenção que poderia significar um avanço no desenvolvimento tecnológico e econômico do país, pode-se entender que a discriminação legal estaria desatendendo ao interesse do desenvolvimento tecnológico e econômico e atendendo políticas públicas embasadas em resultados imediatistas ou em claro suporte de grupos de interesse. No mais, toda e qualquer restrição a direito fundamental deverá atender ao princípio da proporcionalidade.

Assim sendo, não se trata de um simples privilégio instituído por lei que deva ser interpretado de forma restritiva, mas de uma liberdade ou mesmo um direito fundamental assegurado como tal, que deve ser interpretado de forma ampla, atendendo-se, também, às finalidades constitucionalmente impostas nesta interpretação. Ou seja, deve ser realizada verdadeira ponderação de interesses entre o direito à proteção patentária, a livre concorrência, a liberdade de iniciativa e o direito ao desenvolvimento científico e tecnológico.

Consequentemente, na medida em que a possibilidade de patenteamento de alguns materiais genéticos tem sem mostrado uma vantagem mercadológica na indústria farmacêutica, estudos devem ser realizados para confirmar se faz sentido a restrição legislativa às invenções biotecnológica. Entendemos que, se há uma vantagem competitiva ao patenteamento destes materiais biológicos, atraindo players e investimentos para países que concedam o patenteamento, deve-se realizar alteração legislativa e na prática nacional, para que ofereçamos um mercado nas mesmas condições.

Note-se, então, que a LPI optou pela enunciação expressa do que não pode ser objeto de patente, seja por não ser invenção, seja por proibição baseada na violação à moralidade, ordem pública e bons costumes. Em princípio, tudo é invento, salvo as exclusões listadas no art. 10, da $\mathrm{LPI}^{72}$. Assim, em regra, é patenteável toda solução técnica para um problema técnico (invenção) que seja nova, não seja óbvia para um técnico no assunto, e

71 DIAFÉRIA, Adriana. Patente de genes humanos e a tutela dos interesses difusos: o direito ao progresso econômico, científico e tecnológico. Rio de Janeiro: Lumen Juris, 2007. p. 176.

72 BARBOSA, Pedro Marcos Nunes; e BARBOSA, Denis Borges. O Código da Propriedade Industrial conforme os Tribunais - comentado com precedentes judiciais. Fornecido pelo segundo autor, por e-mail, em dezembro de 2013. p. 6. permitida reprodução ilimitada sem intervenção humana em cada caso $^{73}$.

Também, a construção do art. 18, da LPI, do "não dever ser" fixa a concessão do privilégio de forma ampliativa, já que toda e qualquer hipótese não constante das proibições elencadas nesses dispositivos legais poderão dar margem à sua concessão, ao reconhecimento e à proteção pelo Estado ${ }^{74}$.

De uma forma geral, quanto aos materiais biológicos meramente isolados, estes seriam meras descobertas, por não apresentarem diferença para os produtos da natureza. Desta forma, mesmo que não houvesse a exclusão legal, pelo inciso IX, do art. 10, não haveriam de ser consideradas como invenção, com base no inciso I.

Denis Borges Barbosa ressalta que a não-privilegiabilidade do isolamento dos produtos encontrados na natureza deveria estar no art. 18:

[...] não se pode decretar o que é, ou não, invento, eis
que ser - na definição clássica - uma solução técnica
para um problema técnico é uma questão de fato. A
listagem do art. 10 constrói tal noção, mas não pode
determinar, por exemplo, que um conhecimento que
leve a uma solução técnica para um problema técnico
deixe de ser invento. A lei pode fazer com que algo
que seja um invento deixe de ser patenteado; mas o
locus para tanto é o art. $18 .^{75}$

Tecnicamente, entendemos que a associação de determinada sequência genética à sua função implica em mera descoberta. Tal descoberta é de extrema importância, mas trata-se de avanço que deve integrar a base do conhecimento científico. Por outro lado, a utilização da sequência em determinado processo ou produto distinto, sem que se trate de desdobramento óbvio da função identificada, poderia ser considerada como invenção.

Então, em resumo, quanto às sequências genéticas isoladas, há a vedação categórica e, no nosso entendimento, de toda sorte, seriam meras descobertas. Quanto aos demais produtos encontrados na natureza, estes deverão ser afastados do conceito de descoberta, mediante verificação no caso concreto de diferença estrutural e funcional.

73 BARBOSA, Pedro Marcos Nunes; e BARBOSA, Denis Borges. Op. cit.. p. 7.

74 DEL NERO, Patrícia Aurélia. Propriedade Intelectual: A tutela jurídica da biotecnologia. São Paulo, SP: Ed. Revista dos Tribunais, 1998. p. 78.

75 BARBOSA, Denis Borges. Op cit.. p. 14. 
Ressaltamos, ainda, que nem tudo encontrado naturalmente é biológico, já que envolve a significação de "vida". Desta forma, peca a legislação nacional ao fazer a exclusão apenas dos "materiais biológicos encontrados na natureza", deixando margem para a apropriação de produtos não-biológicos encontrados na natureza. Certamente, estes produtos não poderiam ser patenteados, por se tratarem de descobertas, caso não apresentassem diferença estrutural e funcional, mas verifica-se a atecnia legislativa que poderia ser evitada com a simples exclusão do inciso IX, do art. 10, da LPI.

Outro ponto que pode ser destacado é que, pelo teor da lei, não é invenção "inclusive o genoma ou germoplasma de qualquer ser vivo natural e os processos biológicos naturais". Assim, uma primeira conclusão sobre a possibilidade de patenteamento dentro da legislação brasileira é de que podemos admitir o patenteamento da sequência genética de seres vivos não-naturais. Mas o que seriam os seres vivos não-naturais? Utilizando-se o termo da prática jurisprudencial norte-americana, seres naturais são os produtos da natureza, ou seja, aqueles que ocorrem naturalmente e que não decorram da inventividade humana. Consequentemente, seres não-naturais seriam aqueles que não ocorreriam naturalmente. Um exemplo seriam os organismos geneticamente modificados.

Desta forma, as sequências genéticas, com funções identificadas, de organismos geneticamente modificados poderiam ser abraçadas pela patente, já que não incluídas na vedação categórica, bem como não se confundem com as descobertas, tendo em vista sequer serem encontradas na natureza. Outra possibilidade de patenteamento, também, seria o DNA recombinante e, por vezes, caso seja distinta da encontrada na natureza, a proteína recombinada.

Quanto ao cDNA, trata-se de DNA sintético, distinto estruturalmente do DNA natural, mas contendo idêntica informação genética, sendo complementar (de forma natural) ao mRNA, que, por sua vez, por ser um produto da natureza por excelência, não atenderia ao conceito de invenção ${ }^{76}$.

76 Destacamos, ainda, que o cDNA é passo obrigatório em pesquisas, sendo óbvio e necessário. "Entre as tecnologias de análise da expressão gênica em larga escala, as principais e mais rentáveis, em termos de quantidade e qualidade da informação gerada, são (i) sequenciamento em larga escala de bibliotecas de cDNA, gerando a informação conhecida como EST (expressed sequence tags ou etiquetas de sequências transcritas); (ii) a tecnologia denominada
Todavia, recomendamos que seja dado o tratamento de invenção ao cDNA, diante do cenário legislativo e prática internacional, para que seja atingida a homogeneização do tema, com base na diferença funcional por sua maior utilidade.

Ressaltamos, ainda, o art. 18, da LPI, que enumera situação de impossibilidade de patenteamento, incluindo, ali o todo ou parte dos seres vivos, poder-se-ia entender as sequências genéticas como parte dos seres vivos.

Art. 18. Não são patenteáveis:

III - o todo ou parte dos seres vivos, exceto os microrganismos transgênicos que atendam aos três requisitos de patenteabilidade - novidade, atividade inventiva e aplicação industrial - previstos no art. $8^{\circ}$ e que não sejam mera descoberta.

Parágrafo único. Para os fins desta Lei, microrganismos transgênicos são organismos, exceto o todo ou parte de plantas ou de animais, que expressem, mediante intervenção humana direta em sua composição genética, uma característica normalmente não alcançável pela espécie em condições naturais.

De toda sorte, esta seria uma interpretação ampla dada a uma restrição a direito fundamental, conforme visto anteriormente, o que não deve ser aceito. Ou seja, à restrição deve-se dar a interpretação mais estrita, que atenda às finalidades da lei. Assim sendo, não há de se confundir a sequência genética com a parte de um ser vivo, até mesmo porque, quando a lei quis se referir ao genoma ou sequências genéticas, mesmo que de forma genérica, o fez de forma expressa (art. 10, IX, e parágrafo único, do art. 18, ambos da LPI).

Pelo estudo sistemático dos referidos dispositivos legais, pode-se atestar o seguinte: (i) sequências naturais ou isoladas não seriam invenção; (ii) demais materiais biológicos encontrados na natureza, meramente isolados, não seriam invenção, (iii) materiais biológicos não encontrados na natureza são invenção (por exemplo, os geneticamente modificados); (iv) materiais não-biológicos meramente isolados e encontrados na natureza são descobertas e não poderiam ser objeto de patente; (v) materiais não-biológicos, mesmo que encontrados na

SAGE (análise seriada da expressão gênica); (iii) microarrays ou chips de DNA. (...) As bibliotecas (de cDNA) são preparadas a partir de mRNA isolado das amostras de interesse, utilizando a enzima transcriptase reversa, que gera um DNA complementar ao mRNA." Destacamos que, nas 3 tecnologias citadas, há o uso do cDNA como etapa óbvia e necessária. MARQUES, Marilis do Valle; e SILVA, Aline Maria da. Genômica funcional: transcriptoma. In MIR, Luís (org.). Genômica. São Paulo, SP: Atheneu, 2004. p. 123. 
natureza, poderiam ser objeto de patente, caso atendam aos requisitos de diferença estrutural e funcional; (vi) o cDNA tem sido entendido como invenção e, apesar de veicular parte da informação contida no genoma, não se confunde com o conceito de genoma e poderá ser patenteado - de toda forma, não é natural, mas, sim, sintético - ou seja, não há vedação expressa na lei brasileira; e (vii) o DNA recombinante é invenção e poderá ser patenteado já que não seria natural, por excelência; por outro lado, a proteína recombinada, caso idêntica à encontrada naturalmente, não seria considerada invenção, por ausência de diferença funcional.

Verifica-se, do estudo da tendência do processo de concessão de patentes, que os países mais industrializados, antes de adotar algum sistema de regulamentação da propriedade intelectual, buscaram assegurar e garantir determinado nível de desenvolvimento tecnológico, científico e industrial - ou seja, a tendência é de não se reconhecer direitos às patentes antes do atingimento de determinado nível de desenvolvimento nacional ${ }^{77}$. Enfim, a experiência histórica demonstra que a maioria dos países adotou proteção fraca e incompleta até alcançarem estágios avançados de desenvolvimento e muitos violaram os direitos de patentes de outros paí$\operatorname{ses}^{78}$. Mas o Brasil tem cenário diferenciado, no que se refere à disponibilidade de recursos genéticos, que merece estudo apropriado, por ser considerado um país "megadiverso" "79.

Desta forma, é impositivo que estudos sejam feitos para que o cenário nacional seja analisado: qual o nível

77 DEL NERO, Patrícia Aurélia. Propriedade Intelectual: A tutela jurídica da biotecnologia. São Paulo, SP: Ed. Revista dos Tribunais, 1998. pp. 266-267.

78 BRASIL. CÂMARA DOS DEPUTADOS. Projeto de Lei n. 5402/2013. Disponível em: http://www.camara.gov.br/proposicoesWeb/prop_mostrarintegra;jsessionid $=9716$ B7CC43354ED6 CCF44E5AE7249BEB.node2? codteor $=1090597 \&$ filename $=$ Avul so+-PL+5402/2013. Acesso em 02 de setembro de 2016. p. 7.

79 País de megadiverside é termo técnico usado pela Conservação Internacional, organização não governamental, sediada em Washington D.C., nos Estados Unidos, com escritório no Brasil, em Belo Horizonte, Minas Gerais, que visa à proteção de hotspots de biodiversidade, áreas selvagens ou regiões marinhas de alta biodiversidade ao redor do globo. O termo é usado para designar os países mais ricos em biodiversidade do mundo. O número de plantas endêmicas - aquelas que só existem no país e em nenhum outro lugar - é o critério principal para que ele seja considerado 'de Megadiversidade'. Outros critérios são o número de espécies endêmicas em geral e o número total de mamíferos, pássaros, répteis e anfíbios. CONSERVAÇÃO INTERNACIONAL - BRASIL. Disponível em: http://www.conservation.org.br/como/index.php?id=11. Acesso em 04 de setembro de 2016. de desenvolvimento biotecnológico brasileiro, levando-se em consideração, também, que o Brasil é um dos países mais ricos em biodiversidade ${ }^{80}$ ? É necessário que saibamos converter a riqueza de biodiversidade em ferramenta para a competitividade ${ }^{81}$.

Há, então, algumas premissas: (i) existe um potencial competitivo nas criações com base em produtos e processos biológicos; (ii) o Brasil é um país rico em biodiversidade - ou seja, possui vasta matéria-prima a ser pesquisada para utilização na biotecnologia; (iii) tais pesquisas envolvem investimentos de grande monta que necessitam da garantia de alguma contrapartida; (iv) o reconhecimento de direitos de propriedade intelectual sobre as criações advindas de tais pesquisas pode funcionar como esta garantia aos investidores; (v) o sistema de direitos de propriedade intelectual deve ser claro quanto às possibilidades de patenteamento e pautar-se na vedação à proteção para descobertas, para garantir o desenvolvimento científico.

A ABRABI (Associação Brasileira de Empresas de Biotecnologia), em 1991², ou seja, há mais de duas décadas, manifestou-se contrária a qualquer forma de privilégio industrial ou exploração comercial do organismo humano e de suas partes constituintes, mas entendia válidas todas as aplicações da ciência e da técnica na produção de bens e serviços que digam respeito ao diagnóstico, ao tratamento corretivo e à prevenção de distúrbios da saúde humana.

Todavia, já em 2005, tal Associação, por seu Presidente à época, Sr. Antônio Paes de Carvalho, em audiência da CPI da Biopirataria, manifestou opinião no sentido de que, se o Brasil insistisse em não patentear nossas moléculas mais importantes, o País ficaria isolado do resto do mundo com relação à Biotecnologia, ressaltando que a legislação brasileira não concede patentes para os seres vivos naturais ou suas partes e, além disso, impede o patenteamento de extratos e substâncias

80 CONSERVATION INTERNATIONAL DO BRASIL. Megadiversidade. Disponível em: http://www.conservation.org.br/ como/index.php?id=11. Acesso em 02 de setembro de 2016.

81 AMBIENTE BRASIL. Biodiversidade: ferramenta para a competitividade. Disponível em: http://ambientes.ambientebrasil. com.br/gestao/artigos/biodiversidade\%3A_ferramenta_para_a_ competitividade.html. Acesso em 02 de setembro de 2016.

82 SCHOLZE, Simone Henriqueta Cossetin. Os direitos de propriedade intelectual e a biotecnologia. Faculdade de Direito da Universidade de Brasília, Agosto de 1997. Disponível em: http://seer. sct.embrapa.br/index.php/cct/article/view/8916/5036. Acesso em 02 de setembro de 2016.p. 50-51. 
químicas puras isoladas da natureza ${ }^{83}$. Destacou, ainda, que o inventor brasileiro precisa sair do País ${ }^{84}$ para obter proteção aos seus inventos. Ainda, deu como exemplo o caso do produto curaria, um relaxante muscular utilizado em cirurgias, que foi levado para a Europa e transformado quimicamente - um medicamento de origem brasileira que foi aproveitado economicamente no exterior. Em suas palavras ${ }^{85}$ :

\section{"É inadmissível que o Brasil, economia importante, se recuse a estimular o patenteamento dessas substâncias de moléculas puras. (...) O Brasil é um país megadiverso. Essa política também pode levar à biopirataria."}

Verifica-se, então, que o Brasil, ao não permitir, ao menos pela letra fria da lei, o patenteamento de alguns materiais genéticos, encontra-se em posição afastada de muitos modelos internacionais, dificultando a harmonização do sistema, causando dificuldades ao inventor e investidor biotecnológico.

Elaboramos um breve resumo com as principais informações contidas em estudo disponibilizado pelo INPI, apenas para que se possa verificar a posição do Brasil diante da posição de alguns países, com relação à possibilidade de patenteamento ou não de materiais biológicos. ${ }^{86}$

\section{a)Estados Unidos ${ }^{87}$}

Os Estados Unidos da América são signatários da

83 Este mesmo posicionamento também consta de palestra oferecida pelo Sr. Antônio Paes de Carvalho, no $8^{\circ}$ encontro de Propriedade Intelectual e Comercialização de Biotecnologia, ocorrido de 20 a 22 de junho, de 2005, no Hotel Rio Othon Palace, Rio de Janeiro. Disponível em: http://www.redetec.org.br/publique/media/antonio_paes.pdf. Acesso em 30 de agosto de 2016.

84 Verificando-se o sítio da FIOCRUZ, percebemos que alguns pesquisadores nacionais buscam proteção patentária no exterior. Por exemplo, Ricardo Galler e Marcos Freire buscaram proteção na Alemanha, Inglaterra, França, México e Índia para o cDNA infeccioso de febre amarela. Disponível em: http://www.fiocruz.br/ioc/cgi/ cgilua.exe/sys/start.htm?sid=11. Acesso em 30 de agosto de 2016.

85 AGÊNCIA CÂMARA DE NOTÍCIAS. Abrabi reclama falta de patenteamento de moléculas puras. 23 de novembro de 2005 , às 17:02. Disponível em: http://www2.camara.leg.br/camaranoticias/ noticias/79407.html. Acesso em 30 de agosto de 2016.

86 Estudo Comparativo dos Critérios de Patenteabilidade para Invenções Biotecnológicas em diferentes países. Julho de 2007. Disponível em: http://www.inpi.gov.br/images/stories/Estudo_Comparativo_dos_Critriosde_Petenteabilidadepara_Invenes_Biotecnolgicas_em_Diferentes_Pases1.pdf. Acesso em 30 de agosto 2016.

87 FREITAS, Rogério Edivaldo; e ZUCOLOTO, Graziela Ferrero. Propriedade Intelectual e aspectos regulatórios em biotecnologia: Estados Unidos. In Propriedade Intelectual e Aspectos Regulatórios em Biotecnologia. FREITAS e ZUCOLOTO (org.) Rio de Janeiro: IPEA, 2013.
Convenção da União de Paris (CUP), bem como do Acordo TRIPs (Trade Related Aspects of Intellectual Property Rights), portanto, buscam promover a proteção sobre as criações intelectuais. A base legal norte-americana, de forma geral, encontra-se no Título 35 do Código dos Estados Unidos, devendo a patente ser examinada com base no Manual do Procedimento do Exame de Patentes (MPEP) do Escritório de Patentes (USPTO). Neste sentido, impõe-se o atendimento a alguns requisitos de patenteabilidade: que se trate de processo, máquina, manufatura ou composição de matérias; que seja novo, útil e não óbvio, além de haver suficiência descritiva no pedido.

Nos Estados Unidos, o cenário é de presença de mão-de-obra altamente qualificada e de empresários que investem em capital de risco, que condicionam as taxas de nascimento e o bom desempenho da indústria biotecnológica. São apontados como fatores que conduziram a um amplo processo de recondução de investimentos dos departamentos universitários para o setor privado a decisão no Caso Chakrabarty e o Bayh-Dole Act. Todavia, mesmo em mercados desenvolvidos, a contribuição da indústria privada não é o fator determinante para a evolução da base científica, tendo em vista o caráter "quase bem público" da pesquisa científica. Algumas características do cenário norte-americano podem ser resumidas em: (i) particularidade da trajetória histórica de acúmulo de conhecimento e articulação entre as universidades e o setor produtivo; (ii) aportes governamentais; e (iii) visão pragmática quanto ao uso dos conhecimentos científicos e atribuição de direitos de propriedade.

Esclarecemos que foi verificado anteriormente a legislação norte-americana e sua prática de patenteamento de alguns materiais genéticos, especialmente no que se refere aos produtos isolados e purificados ou extraídos da natureza, em Capítulo específico, para o qual remetemos o leitor. De uma forma geral, quanto aos materiais genéticos, as sequências isoladas não têm mais a proteção reconhecida, por serem entendidas como descobertas, mas apenas o cDNA.

b) Europa ${ }^{88}$

Trata-se de cenário de articulação supranacional, havendo forte participação dos Estados envolvidos e

88 FREITAS, Rogério Edivaldo; e BIANCHI, Carlos. Propriedade Intelectual e aspectos regulatórios em biotecnologia: União Europeia. In Propriedade Intelectual e Aspectos Regulatórios em Biotecnologia. FREITAS e ZUCOLOTO (org.) Rio de Janeiro: IPEA, 2013. P. 60 
de grandes corporações, que alcançou sua maturidade técnica, produtiva e regulatória na década de 90, havendo uma tentativa de se reproduzir a experiência norte-americana.

A União Europeia é advinda de processo iniciado após a Segunda Guerra Mundial, objetivando união econômica e política, para fortalecimento do bloco diante do resto do mundo, para maior influência. Assim, em um destes esforços, diante da necessidade de unificação dos sistemas de patentes, ocorreu, em 1973, a Conferência Diplomática de Munique para o estabelecimento do Sistema Europeu para a Concessão de Patentes, sendo assinada a Convenção Europeia de Patentes. O Escritório Europeu de Patentes constitui o órgão executivo da Organização Europeia de Patentes e tem como objetivo estabelecer as regras de proteção patentária harmonizadas para os países membros.

No que se refere ao cenário econômico, reforça-se que o padrão de concentração das atividades em biotecnologia relaciona-se a fatores específicos como a força relativa no campo de Ciências da Vida, fatores políticos de promoção pública dessa área e a presença de indústrias específicas vinculadas ao segmento.

Os requisitos de patenteabilidade, de forma geral, são: a atividade inventiva, a novidade e a aplicação industrial. As invenções biotecnológicas que concernem a este trabalho são regidas pela Diretiva 98/44 Capítulo I, "Patenteabilidade", podendo-se destacar o art. $3^{\circ}$, que permite que materiais isolados da natureza sejam objeto de invenção, mesmo que preexistam em seu estado natural. $\mathrm{O}$ art. $5^{\circ}$, ao referir-se expressamente às sequências genéticas, afirma que estas não podem constituir invenções patenteáveis, nem mesmo a sequência parcial, no item 1. No item 2, deste mesmo artigo, afirma que a sequência, parcial ou não, pode constituir invenção, desde que isolada, mesmo que sua estrutura seja idêntica a do produto natural, devendo a sua aplicação industrial ser exposta concretamente no pedido (item 3). Ou seja, a redação é controversa o que leva a problemas de ordem prática.

$$
\text { c) Japão }{ }^{89}
$$

Assim como os Estados Unidos, o Japão é signatário

89 SOUSA, André Gervásio de. Propriedade Intelectual e aspectos regulatórios em biotecnologia: Japão. In Propriedade Intelectual e Aspectos Regulatórios em Biotecnologia. FREITAS e ZUCOLOTO (org.) Rio de Janeiro: IPEA, 2013 da CUP, desde 1899, bem como do TRIPs. A base legal do sistema de patentes, quanto às invenções biotecnológicas e, em especial, quanto aos materiais genéticos, é constituída pela Legislação Japonesa Relacionada à Propriedade Industrial (seções 29 e 36), de 2004, pelo Guia de Exames de Patentes e de Modelo de Utilidade, de 2007, que trata, na Parte VII, sobre o Guia de Exames para Invenções em Campos Específicos (como por exemplo, Biológico e Medicinal).

Os requisitos de patenteabilidade são, de uma forma geral, a aplicabilidade industrial, a novidade, a não obviedade e a suficiência descritiva.

O Japão apresentou defasagem com relação ao patenteamento biotecnológico, o que induziu o poder público a implementar medidas diversas para o fomento da inovação biotecnológica, podendo-se nomear cinco medidas: (i) uma lei para a promoção da transferência tecnológica entre universidades e empresas (1998); (ii) uma lei para revitalização da indústria (à semelhança da Lei Bayh-Dole norte-americana, em 1999); (iii) desenvolvimento de estratégias básicas para a criação da indústria biotecnológica (1999); (iv) instituição de nova estratégia desenvolvimentista para a renovação do Japão (2000); e (v) o delineamento de estratégias para a indústria biotecnológica (2002).

A legislação patentária japonesa, a partir de um conceito amplo de novidade e de aplicabilidade industrial, considera os fragmentos de DNA, genes e proteínas recombinantes como compostos químicos, facilitando o patenteamento. A prática assemelha-se à europeia, em que o fragmento de DNA com alta homologia a uma sequência conhecida, com uma função conhecida, não preenche o critério da novidade, a menos que o inventor prove que o fragmento tem uma função que era previamente desconhecida e que seja aplicável industrialmente.

\section{d) $\operatorname{China}^{90}$}

À semelhança do Brasil, a China também é um país rico em diversidade biológica assim como a Índia. ${ }^{11}$

90 ZUCOLOTO, Graziela Ferrero. Propriedade Intelectual e aspectos regulatórios em biotecnologia: China. In Propriedade Intelectual e Aspectos Regulatórios em Biotecnologia. FREITAS e ZUCOLOTO (org.) Rio de Janeiro: IPEA, 2013.

91 COSTA, Cíntia Reis; PARANHOS, Julia; e VASCONCELLOS, Alexandre Guimarães. Brasil, Índia e China: o marco legal da biodiversidade e a proteção patentária no âmbito do sistema farmacêutico de inovação. Disponível em: http:/ /www.altec2013.org/ programme_pdf/655.pdf. Acesso em 04 de setembro de 2016. Pp. 
Somente a partir da década de 1980 a China tornou-se membro da OMPI (Organização Mundial da Propriedade Intelectual), ratificando os principais acordos, como a CUP e o TRIPs. ${ }^{92}$

A Lei de Patentes da República Popular da China foi instituída em 1984, sofrendo revisões nos anos de 1992 e 2000, sendo que, após este período, algumas regulamentações específicas acerca da biotecnologia têm sido implementadas, a exemplo, o Decreto de n. 306, do Conselho de Estado da República da China, de junho de 2001.

Os critérios de patenteabilidade são: inventividade, novidade e aplicabilidade prática, além da suficiência descritiva; e estão descritos no art. 22, do Capítulo II, da Lei de Patentes Chinesa.

De acordo com a experiência chinesa, microorganismos isolados de uma cultura e desde que tenham uso industrial particular podem ser patenteados, assim como os materiais genéticos, por serem considerados substâncias bioquímicas, desde que isolados e purificados.

\section{Considerações finais}

O patenteamento de invenções biotecnológicas e, principalmente, do todo e partes dos seres vivos sempre foi cercado de controvérsias em vista do entendimento segundo o qual o sistema de patentes foi concebido para a proteção dos desenvolvimentos tecnológicos inanimados. Ressalta-se ainda que questões éticas e religiosas também influenciaram esse tipo de proteção, de forma a restringir as patentes aos seres vivos. Busca-se evitar assim a tentativa de o homem atuar como falso Deus por meio das manipulações de organismos vivos.

9-11.

"Em torno de 31 mil espécies de plantas são nativas, o que representa aproximadamente um oitavo do total mundial, incluindo centenas de espécies presentes exclusivamente no país. Adicionalmente, 200 mil espécies de animais conhecidos e 30 mil espécies de microorganismos são encontradas no país. (...) Os recursos chineses são únicos: A China concentra 56 grupos minoritários, muitos vivendo em áreas isoladas (...) oferece grande portencial para o estudo de doenças genéticas. " ZUCOLOTO, Graziela Ferrero. Propriedade Intelectual e aspectos regulatórios em biotecnologia: China. In Propriedade Intelectual e Aspectos Regulatórios em Biotecnologia. FREITAS e ZUCOLOTO (org.) Rio de Janeiro: IPEA, 2013. p. 107

92 ZUCOLOTO, Graziela Ferrero. Propriedade Intelectual e aspectos regulatórios em biotecnologia: China. In Propriedade Intelectual e Aspectos Regulatórios em Biotecnologia. FREITAS e ZUCOLOTO (org.) Rio de Janeiro: IPEA, 2013. p. 107),
Inúmeras discussões e decisões judiciais nos Estados Unidos e Europa sobre patenteamento de seres vivos ocorreram desde 1950, não obstante o fato de já existir desde 1930 o Plant Patent Act nos Estados Unidos que reconheceu as variedades de plantas como objetos passíveis de proteção patentária.

Relevam-se duas decisões judiciais principais, emitidas pela Suprema Corte, que procuraram dirimir as controvérsias e estabeleceram parâmetros técnicos para assegurar o patenteamento da biotecnologia. O Caso Chakrabarty é o mais emblemático, pois aceitou o patenteamento de produtos da natureza que sofressem intervenção humana, afastando-se assim influência de preconceitos éticos e morais, pois "evertbing under the Sun that is made by man [may be patentable]".

Com base nessa compreensão da intervenção humana sobre organismos da natureza, a mesma Suprema Corte restabeleceu os contornos proprietários do patenteamento de seres vivos e direcionou-se no sentido de não se reconhecer a possibilidade de patentear sequências genéticas isoladas, à luz da Teoria dos Produtos da Natureza. Tal decisão foi importante na medida em que estabeleceu parâmetros para a distinção entre descoberta e invenção, especificamente no que se refere às sequências genéticas.

Se, por um lado, a decisão da Suprema Corte afastou a proteção para a sequência de DNA isolado, o cDNA teve a sua proteção reconhecida. Claramente, existe, em ambos os casos, a diferença estrutural para o produto encontrado na natureza, sendo que, na sequência isolada, a Suprema Corte não reconheceu a diferença funcional entre o DNA isolado e o cDNA. Por outro lado, apesar de compreendermos que o cDNA veicula o mesmo conteúdo informacional que o DNA isolado, a Suprema Corte entendeu por permitir o patenteamento deste cDNA, vislumbrando a diferença funcional pela maior utilidade.

A importância do Caso Myriad foi construir bases para uma Doutrina dos Produtos da Natureza, esclarecendo algumas premissas para aplicação em casos concretos, tendo em vista a necessária adequação ao conceito de invenção. A importância desse caso justifica-se ainda como parâmetro para modificações na legislação brasileira, de forma a flexibilizá-la e permitir uma proteção maior aos inventos da natureza, tendo em vista a sistematização ali estabelecida para a compreensão da possibilidade de patenteamento ou não de alguns ma- 
teriais genéticos.

Com base na decisão do Caso Myriad, pode-se, resumidamente, alcançar os seguintes pontos conclusivos para a proteção patentária:

(i) O produto deverá ser verdadeiramente uma invenção e não uma simples descoberta;

(ii) Um produto idêntico ao preexistente, mesmo que derivado de uma nova fonte, não atende ao requisito de novidade;

(iii) Um produto meramente extraído e que não apresenta nenhuma alteração não poderá ser patenteado;

(iv)Um produto isolado deverá ser bem mais útil do que a sua forma natural;

(v)O produto só será uma invenção se apresentar diferença estrutural e funcional com relação a um produto de ocorrência natural;

(vi)A caracterização da diferença funcional pode advir de uma maior utilidade significativa (greater) (novo valor terapêutico e comercial).

Quando do patenteamento de sequências genéticas, verifica-se que está em jogo, a informação genética necessária à inovação tecnológica, por se tratarem de ferramentas básicas e preponderante para novos desenvolvimentos.

Dessa forma, a questão da possibilidade de patenteamento ou não, antes da análise do texto legal, deve passar por uma análise de política legislativa, ponderando-se os interesses que estão em jogo: necessidade de se garantir o retorno aos investimentos realizados; a necessidade de se proteger a biodiversidade como patrimônio de uma nação; e a necessidade de se incentivar a realização de pesquisas para promoção do desenvolvimento científico e tecnológico. Esse é o procedimento a ser adotado no Brasil cuja lei de patentes é vacilante quanto à proteção de seres vivos e invenções biotecnológicas.

\section{REFERÊnCIAS BIBLIOGRÁfICAS}

BARBOSA, Denis Borges. Relatório de Análise da incorporação do conhecimento levantado e sua possivel aplicaşão no Brasil Contrato n. 2010/000426. PROGRAMA DAS NACÕES UNIDAS PARA O DESENVOLVIMENTO. SERVICSOS DE CONSULTORIA. PROJETO
PNUD/BRA/06/032. BRASÍLIA. Termo de Referência n.133963. Fornecido pelo autor, por e-mail, a cladelacerda@gmail.com, em dezembro de 2013. Sem data de lançamento.

BEAUCHAMP, Christopher. Patenting nature: a problem of history. Stanford Tecnology Law Review, Brooklyn, v. 16, n. 296, 25 set. 2012. Disponível em: http://papers.ssrn.com/sol3/papers.cfm?abstract_id $=2152105$. Acesso em: 30 de agosto de 2016.

The pure thoughts of Judge Hand: A historical note on the patenting of nature. [S.l.: s.n., 2011]. Disponível em: http://www.law.nyu.edu/sites/default/ files/ECM_PRO_071307.pdf. Acesso em: 27 de julho de 2016.

BELCHER, Brian and HAWTIN, Geoffrey. A patent on life: ownership of plant and animal research. In: NAIR, Krg; KUMAR, Ashok. Intellectual Property Right. New Delhi: Allied Publishers Ltd., 2005. p. 263-298. Disponível em: http://books.google.com.br/ books?id=orZWiAIhAzAC\&pg=PA282\&lpg $=$ PA2 28 $\& \mathrm{dq}=\mathrm{key}+$ dismukes + chakrabarty\&source $=$ bl\&ots $=\mathrm{L}$ 12MsQWQup\&sig=jV0KFY9EivNyXowiJ37amhW4f $70 \& h l=p t-B R \& s a=X \& e i=J j B p U 8 T f C Y r h y g G \_m 4 H g$ $\mathrm{BA} \& \mathrm{ved}=0 \mathrm{CEOQ} 6 \mathrm{AEwAw} \# \mathrm{v}=$ onepage $\& \mathrm{q}=\mathrm{key} \% 20$ dismukes $\% 20$ chakrabarty\&f=false. Acesso em: 25 de julho de 2016.

BENNETT, I. C.; GATTAS, M.; TEH, B.T. The Genetic Basis of Breast Cancer and its Clinical Implications. Aust. N. Z. J. Surg, [S. 1.], v. 2, n. 69, p. 95 - 105, fev. 1999.

BOWMAN, Andrew. Genes 101: Are human genes patentable subject matter? Rich. J. L. \& Tech. [S.1.], v. 18, n. 4, [s. d.]. Disponível em: http://jolt.richmond.edu/ v18i4/article15.pdf. Acesso em: 27 de julho de 2016.

COOK-DEGAN, Robert. HEANEY, Christopher. Gene Patents and Licensing: Case Studies Prepared for the Secretary's Advisory Committee on Genetics, Health and Society. USA: Nature, 2010. Disponível em: http://www.nature.com/gim/journal/v12/n1s/full/ gim2010138a.html. Acesso em 23 de julho de 2016

DIAFÉRIA, Adriana. Patente de Genes Humanos e a tutela dos direitos difusos. O direito ao progresso econômico, científico e tecnológico. Rio de Janeiro: Lumen Juris, 2007.

GREELY, Henry T. The future of gene patents and the 
implications for medicine. JAMA Internal Medicine. Volume 173, Number 17. Stanford University: September 23, 2013. Disponível em: http://papers.ssrn.com/ sol3/papers.cfm?abstract_id $=2325679$. Acesso em: 25 de julho de 2016.

HARKNESS, Jon M. Dicta on Adrenalin(e): Myriad problems with Learned Hand's Product-of-Nature Pronouncements in Parke-Davis v. Mulford. Disponível em: https://works.bepress.com/jon_harkness/1/. Acesso em 29 de julho de 2016.

Myriad Misunderstandings on Parke-Davis v. Mulford. [S.l.: s.n., 2012]. Disponível em: http://patentlyo.com/patent/2012/05/myriad-parke-davis.html. Acesso em 26 de julho de 2016.

KHAN, Fazal; e KESSLER, Lindsay. Genomics Unbound: The scientific and legal case against patents based on naturally occurring DNA sequences. Nevada Law Journal vol. 13:668. USA: Junho de 2013. Disponível em: http://digitalcommons.law.uga. $\mathrm{edu} / \mathrm{cgi} / \mathrm{viewcontent}$.cgi? article $=1918 \&$ context $=$ fac_ artchop. Acesso em: 27 de julho de 2016.

KHAN, Fazal; e KESSLER, Lindsay. Gene patents no more? Deciphering the meaning of Prometheus. Annals Health L. Informed Consent 19 (2012). USA: 2012. Disponível em http://digitalcommons.law.uga.edu/ fac_artchop/920. Acesso em: 27 de julho de 2016.

MIR, Luís (org.). Genômica. São Paulo, SP: Atheneu, 2004. p. 123.

PASSOS-BUENO, Maria Rita. MOREIRA, Eloísa de Sá. Ferramentas Básicas da Genética Molecular Humana. In: MIR, Luís (org.). Genômica. São Paulo, SP: Atheneu, 2004.

SCHOLZE, Simone Henriqueta Cossetin. Os direitos de propriedade intelectual e a biotecnologia. Brasília: Faculdade de Direito da Universidade de Brasília, Agosto de 1997. Disponível em: http://seer.sct.embrapa.br/index.php/ cct/article/view/8916/5036. Acesso em: 25 de julho de 2016.

VAZ E DLAS, José Carlos. Intellectual property rights protection and the inflow of foreign technology and direct foreign investment: the Brazilian case. Tese submetida à Universidade de Kent em Canterbury como requisite à obtenção do título de Doutor em Filosofia Legal em Agosto de 1993. 
Para publicar na Revista de Direito Internacional, acesse o endereço eletrônico www.rdi.uniceub.br ou www.brazilianjournal.org.

Observe as normas de publicação, para facilitar e agilizar o trabalho de edição. 